\title{
A review of the social-ecological systems framework: applications, methods, modifications, and challenges
}

\author{
Stefan Partelow ${ }^{1,2}$
}

\begin{abstract}
The social-ecological systems framework (SESF) is arguably the most comprehensive conceptual framework for diagnosing interactions and outcomes in social-ecological systems (SES). This article systematically reviews the literature applying and developing the SESF and discusses methodological challenges for its continued use and development. Six types of research approaches using the SESF are identified, as well as the context of application, types of data used, and commonly associated concepts. The frequency of how each second-tier variable is used across articles is analyzed. A summary list of indicators used to measure each second-tier variable is provided. Articles suggesting modifications to the framework are summarized and linked to the specific variables. The discussion reflects on the results and focuses on methodological challenges for applying the framework. First, how the SESF is historically related to commons and collective action research. This affects its continued development in relation to inclusion criteria for variable modification and discourse in the literature. The framework may evolve into separate modified versions for specific resource use sectors (e.g., forestry, fisheries, food production, etc.), and a general framework would aggregate the generalizable commonalities between them. Methodological challenges for applying the SESF are discussed related to research design, transparency, and cross-case comparison. These are referred to as "methodological gaps" that allow the framework to be malleable to context but create transparency, comparability, and data abstraction issues. These include the variable-definition gap, variable-indicator gap, the indicator-measurement gap, and the data transformation gap. A benefit of the framework has been its ability to be malleable and multipurpose, bringing a welcomed pluralism of methods, data, and associated concepts. However, pluralism creates challenges for synthesis, data comparison, and mutually agreed-upon methods for modifications. Databases are a promising direction forward to help solve this problem. In conclusion, future research is discussed by reflecting on the different ways the SESF may continue to be a useful tool through (1) being a general but adaptable framework, (2) enabling comparison, and (3) as a diagnostic tool for theory building.
\end{abstract}

Key Words: collective action; commons; diagnostic research; frameworks; governance; sustainability

\section{INTRODUCTION}

The social-ecological systems framework (SESF) (Ostrom 2007, 2009, Poteete et al. 2010) is a conceptual framework providing a list of variables that may be interacting and affecting outcomes in social-ecological systems (SES). The evolution of the framework is supported by a long history of empirical research on the commons, institutions, and collective action (e.g., Ostrom 1990, Agrawal 2001, Meinzen-Dick et al. 2002, Anderies et al. 2004, Wollenberg et al. 2007, Poteete et al. 2010). However, the SESF is now viewed less as a theoretical framework to advance collective action theory and more as a general tool to diagnose the sustainability of social-ecological systems (Ostrom 2009). This transition has brought wider engagement over the last 10 years, and the framework's core literature (i.e., Ostrom 2007, 2009, Poteete et al. 2010, McGinnis and Ostrom 2014) has now been cited in combination more than 7,700 times (Google Scholar, as of November 2018). However, critical methodological questions remain regarding how the framework can be applied empirically, operationalized in new contexts, and continue to evolve (Hinkel et al. 2015, Leslie et al. 2015, Partelow et al. 2018b).

This article reviews the SESF literature to help examine how and where it has been applied and discusses methodological challenges for applying the framework to guide those interested in critical discussion about future research. First, by reviewing the trends in the peer-reviewed literature and, second, by providing an extensive discussion of different methods and methodological considerations for applying the framework. This article builds on previous reviews by McGinnis and Ostrom (2014), who provide substantial contributions to the framework's conceptual development, and by Thiel et al. (2015) who review 20 articles using the framework for empirical research. This article continues and considerably expands on these two efforts by examining more than 90 articles that engage with the SESF either conceptually, empirically, and/ or for metaanalysis. In the discussion, I critically reflect on how the SESF is inherently related to commons and collective action research, and how this warrants reflection on potential inclusion criteria for variable modification, and ultimately, the framework's continued development. Numerous methodological challenges are discussed for applying the framework for future research. This review and discussion are guided by the following research questions:

- What are the trends in the SESF literature (i.e., sectors, data types, methods used)?

- What are the different ways the SESF is being applied (i.e., types of research)?

- What variable modifications have been suggested to the framework?

- What are the directions forward and potential challenges for the frameworks continued development?

\section{A brief history of the framework}

Although countless articles and books have written far more comprehensively about the evolution of Elinor Ostrom's research on the commons, institutions, and collective action, leading to the SESF, the nature of this article warrants a brief overview. Initiated 
by her book Governing the Commons (1990), Ostrom and many colleagues began accumulating empirical evidence on the variables and types of institutional arrangements that were most likely to enable actors to work together and solve social dilemmas in systems with common-pool resources (CPR) and public goods (Olson 1965, Ostrom et al. 1994, Schlager 2004). Her work directly challenged Garrett Hardin's conclusions in the Tragedy of the Commons (Hardin 1968), showing that resource users are not helpless in their ability to solve social dilemmas, which are exacerbated by the rivalry and excludability characteristics of CPRs, but they can actually develop self-organized institutions to govern the commons without the need for privatizing common property or imposing state regulation.

Based on the early work of many commons scholars, an empirically supported list of variables began to emerge showing the multitude of influences that affect the development of governance institutions (Agrawal 2003, Anderies et al. 2004, Ostrom 2005). These variables became a comprehensive list of social and ecological variables influencing cooperation and selforganized governance under a theory of collective action (Olson 1965, Ostrom 1990, Poteete et al. 2010). Collective action theory in the commons literature explores a central hypothesis that actors can cooperate and self-organize the development of institutions for natural resource governance. However, the success of this cooperation is likely to vary under different social and ecological conditions. It became evident that the development of successful institutional arrangements for governance was in part dependent on understanding complex and interdependent linkages between these social and ecological variables. It soon became difficult to develop a strong set of theoretical claims that any group of variables will influence sustainability outcomes in predictable and generalizable ways across diverse cases. Instead, a proclaimed "nontheoretical" list of variables was conceptualized as a diagnostic checklist, a list of potentially influential variables that can be used to guide the diagnosis of key variables and interactions influencing outcomes; although the framework is not theory neutral, it is inherently rooted in collective action theory. This shift toward a diagnostic approach has been described metaphorically as similar to medical practitioners who diagnose patients with a standardized checklist of key components and interactions in the human body to find the appropriate treatments and to allow easy comparability between patients (McGinnis and Ostrom 2014). The concept of diagnosis can be applied to environmental problems if a list of key variables and interactive processes can be identified, i.e., variables that are common across a wide variety of systems for examination. The SESF proposes a list of generalizable variables that can be used as a diagnostic tool to help solve challenges with the governance of environmental problems (Ostrom 2007, 2009). However, the challenge with a diagnostic checklist that is proclaimed to not be explicitly linked to collective action theory, despite its clear history and evident theoretical construction under collective action theory (Ostrom 1990, 1998, Ostrom et al. 1994, Poteete et al. 2010), is what the theoretical inclusion criteria for new variables will be for modifying the framework.

The SESF is structured into tiers of nested and related concepts and variables (Fig. 1). The first tiers include the Resource System (RS), Resource Units (RU), Governance System (Gov), Actors (A), Social, Economic and Political Settings (S), Interactions (I),
External Ecosystems (Eco), and Outcomes (O). Second-tier variables are nested within each first-tier variable (Table 1). Beyond its visible structure, the framework emerges from the convergence of political theory and institutional economics (North 1990, Ostrom 1990, Coase 1998, Klein 1999). The epistemology of the framework (e.g., what is worth knowing about reality from the use of the framework) places an institutional and anthropocentric lens on the analysis of natural resource use in the commons through suggesting the need to understand how and why cooperation (via collective action and institutions) influences governance arrangements and their ability to achieve sustainable outcomes. However, it is evident that the framework is useful beyond the scope of commons and collective action research, as it has been proposed as a general tool to diagnose the sustainability of SES more generally (Ostrom 2009) and to develop new theories in SES (Cox et al. 2016).

Fig. 1. Conceptualization of the social-ecological systems framework from McGinnis and Ostrom (2014). First-tier variables are shown with their interactions and outcomes.

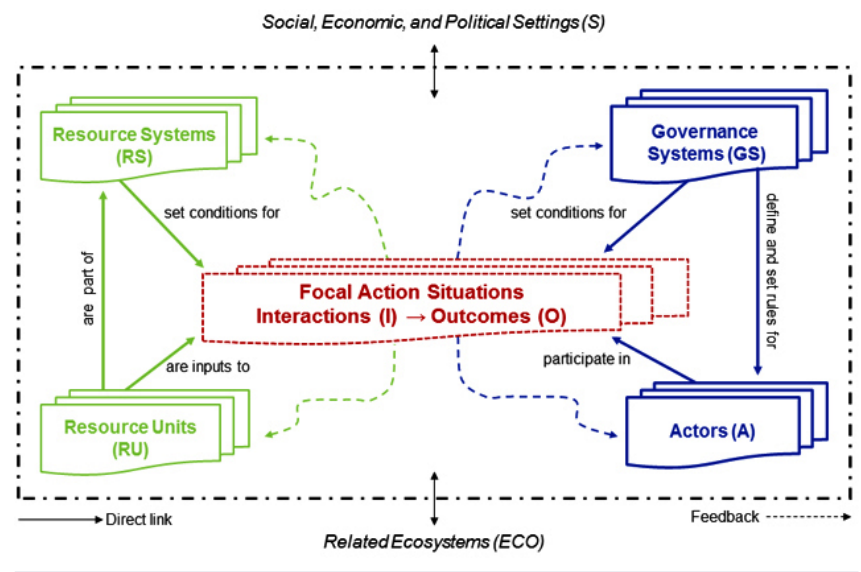

Social-ecological systems and sustainability

The SES concept has evolved into a mainstreamed field of research focused on the interdependent linkages between social and environmental change, and how those interdependent linkages influence the achievement of sustainability goals across different systems, levels, and scales (Berkes and Folke 1998, Liu et al. 2007, Fischer et al. 2015). Social-ecological systems research is focused on understanding many dimensions of system functioning, making it an interdisciplinary field, but also on the development and implementation of normative societal goals, such as those related to sustainability (Gibson 2006, Raworth 2012, Abson et al. 2014). What SES scholars would ultimately like to know is how SES can be sustainable for different people and places around the world. However, with these broad and often ambiguous goals, SES scholarship has become diverse and pluralistic (Miller et al. 2008, Binder et al. 2013, Partelow and Winkler 2016). It associates with many different concepts, theories, and methods under two broad conceptual pillars: (1) understanding SES functioning and (2) understanding all aspects related to the development, implementation, and transformation toward normative sustainability goals. A large majority of SES research attempts, in some way, to link these two core pillars, 
Table 1. The first- and second-tier variables of the social-ecological systems framework from McGinnis and Ostrom (2014).

\begin{tabular}{|c|c|}
\hline \multicolumn{2}{|c|}{$\begin{array}{l}\text { Social, Economic, and Political Settings (S) } \\
\text { S1- Economic development. S2- Demographic trends. S3- Political stability. } \\
\text { S4- Other governance systems. S5- Markets. S6- Media organizations. S7- Technology }\end{array}$} \\
\hline Resource Systems (RS) & Governance Systems (GS) \\
\hline RS1- Sector (e.g., water, forests, pasture) & GS1- Government organizations \\
\hline RS2- Clarity of system boundaries & GS2- Nongovernmental organizations \\
\hline RS3- Size of resource system & GS3- Network structure \\
\hline RS4- Human-constructed facilities & GS4- Property-rights systems \\
\hline RS5- Productivity of system & GS5- Operational rules \\
\hline RS6- Equilibrium properties & GS6- Collective choice rules \\
\hline RS7- Predictability of system dynamics & GS7-Constitutional rules \\
\hline RS8- Storage characteristics & GS8- Monitoring and sanctioning \\
\hline \multicolumn{2}{|l|}{ RS9- Location } \\
\hline Resource Units (RU) & Actors (A) \\
\hline RU1- Resource unit mobility & A1- Number of relevant actors \\
\hline RU2- Growth or replacement rate & A2-Socioeconomic attributes \\
\hline RU3- Interaction among resource units & A3- History or past experiences \\
\hline RU4- Economic value & A4- Location \\
\hline RU5- Number of units & A5- Leadership/entrepreneurship \\
\hline RU6- Distinctive characteristics & A6- Norms (trust-reciprocity)/ social capital \\
\hline \multirow[t]{3}{*}{ RU7- Spatial and temporal distribution } & A7- Knowledge of SES/mental models \\
\hline & A8- Importance of resource (dependence) \\
\hline & A9- Technologies available \\
\hline Interactions (I) & Outcomes $(\mathrm{O})$ \\
\hline I1- Harvesting & O1-Social performance measures \\
\hline I2- Information sharing & O2- Ecological performance measures \\
\hline I3- Deliberation processes & O3- Externalities to other SESs \\
\hline \multicolumn{2}{|l|}{ I4- Conflicts } \\
\hline \multicolumn{2}{|l|}{ I5- Investment activities } \\
\hline \multicolumn{2}{|l|}{ I6- Lobbying activities } \\
\hline \multicolumn{2}{|l|}{ I7- Self-organizing activities } \\
\hline \multicolumn{2}{|l|}{ I8- Networking activities } \\
\hline \multicolumn{2}{|l|}{ I9- Monitoring activities } \\
\hline \multicolumn{2}{|l|}{ I10- Evaluative activities } \\
\hline \multicolumn{2}{|c|}{ Related Ecosystems (ECO) } \\
\hline ECO1-Climate patterns ECO2- Pollut & atterns ECO3- Flows into and out of SES \\
\hline
\end{tabular}

including the SESF. The SESF provides one of many conceptual frameworks attempting to do this, arguably the most comprehensive framework, but many others exist (Binder et al. 2013, Partelow and Winkler 2016).

\section{METHODS}

A systematic review of peer-reviewed literature was conducted from the scholarly databases Scopus and Web of Science. Searches were conducted on both databases (as of January 2018) to find literature directly engaged with the SESF in any context or type of research. Search strings were guided by an extensive list of search terms related to "social-ecological system," "framework," and/ or "Ostrom," resulting in more than 120 articles from both databases. This list was refined manually by reading abstracts, and the full text if necessary, to check for applicability to the scope. Ninety-two articles were included for final review. Each article was read, evaluated, and coded with standardized criteria by two coders, first a research assistant and then the author. Consensus coding was reached on the following categories for each article: source, year of publication, type of research, contextual focus, major discussion points, type of data, type of analysis, variables used, indicators used, and suggested variable modifications.

\section{RESULTS}

\section{Trends and gaps in the social-ecological systems framework} literature

The SESF is extensively cited and associated with other concepts in the broader SES discourse, including other theories, concepts, and frameworks (Binder et al. 2013, Cox et al. 2016). The most common associations are with ecosystem services (Daily 1997, Partelow and Winkler 2016), resilience (Berkes and Folke 1998), and a variety of other environmental governance theories (Folke et al. 2005, Cox et al. 2016), including multilevel governance, polycentric governance, and adaptive comanagement. The crosspollination of literature with broader SES research has created a plurality of nested conceptual approaches regarding the contexts in which the framework is applied and the methodologies for its application (Table 2).

The SESF has been applied to a wide variety of empirical contexts (Table 2). Much of the literature remains focused on commons scholarship, with a large focus on community-based systems such as irrigation systems (Meinzen-Dick 2007, Cox 2014a, Hoogesteger 2015, McCord et al. 2016), small-scale fisheries (Basurto et al. 2013, Leslie et al. 2015, Lozano and Heinen 2015, 
Table 2. The diversity of methods, contexts, and thematic areas under which the social-ecological systems framework is applied are shown with the relevant literature. The specific sectors in which the framework has been applied are shown. Associated concepts and databases related to the framework are indicated.

\section{Type of engagement}

with the SESF

Focus

Meta or large comparative analysis

Quantitative

Qualitative

Mixed

Empirical analysis with single or multiple cases

Quantitative

Qualitative

Mixed

Temporal analysis

Empirical analysis on specific or select variables

Experimental

General development of the framework

Multidimensionality of first-tier variables

Application through mixed methods and disciplinary

approaches

Specifically adding and/or modifying variables. Ontological consistency.

Sector specific

Small-scale fisheries (general)

Sector specific

Use in combination with other approaches or concepts

Coral reef fisheries

Benthic fisheries

Lobster fisheries

Large-scale fisheries

Recreational fisheries

Aquaculture

Marine and coastal systems (general)

Food production systems

Irrigation

Forestry

Pasture/rangelands

Watershed/stormwater management

Drinking water management

Institutional analysis and development (IAD) framework

Use in combination with other approaches or concepts

Othe

Ecosystem services (general)

Payment for ecosystem services

Sustainability science

Resilience

Framework as a boundary object

Associated databases

Social-Ecological Systems Meta-Analysis Database

(SESMAD)

SESGO

SES Library

CPR Database

NIIS Online Database

IFRI Database
Literature

Gutiérrez et al. 2011, Cinner et al. 2012, Rahimi et al. 2016

Thiel et al. 2015

Kelly et al. 2015

MacNeil and Cinner 2013, Leslie et al. 2015

Amblard 2012, Ban et al. 2015, Hoogesteger 2015, Lozano and Heinen 2015, Naiga et al. 2015, Oberlack et al. 2015, London et al. 2017

Ernst et al. 2013, Cox 2014a, Guevara et al. 2016

Epstein et al. 2014a, Ban et al. 2015

Aswani et al. 2013, Falk et al. 2016

McGinnis and Ostrom 2014

Poteete et al. 2010

2015

Gutiérrez et al. 2011, Cinner et al. 2012, Schlüter and Madrigal 2012, Delgado-Serrano and Andres Ramos 2015, Lozano and Heinen 2015, Partelow 2015, Guevara et al. 2016, Rahimi et al. 2016

Cinner et al. 2012, Stevenson and Tissot 2014

Basurto et al. 2013

Hearn 2008, Ernst et al. 2013, Partelow and Boda 2015

Epstein et al. 2014a

Hunt et al. 2013, Arlinghaus et al. 2017, Lanz 2017

Partelow et al. $2018 b$

Schlüter et al. 2013, 2019

Marshall 2015

Meinzen-Dick 2007, Cox 2014a, McCord et al. 2016

Fleischman et al. 2010, Oberlack et al. 2015, Davenport et al. 2016

Cole et al. 2014, Risvoll et al. 2014

Villamayor-Tomas et al. 2014, Bennett and Gosnell 2015, Silva et al. 2015, Flynn and Davidson 2016

Madrigal et al. 2011

Ostrom and Cox 2010, Partelow and Boda 2015, McCord et al. 2016

Ban et al. 2015, Partelow and Winkler 2016, Rova and Pranovi 2017

Yin et al. 2013, Addison and Greiner 2015, Bennett and Gosnell 2015, Rodríguez-Robayo and Merino-Perez 2017

Partelow 2016

Risvoll et al. 2014, Arlinghaus et al. 2017

Hertz and Schlüter 2015, Partelow and Winkler 2016

Cox $2014 b$

https://sesmad.dartmouth.edu/

http://141.48.2.108:8080/ses_db_test/index

https://seslibrary.asu.edu/

https://seslibrary.asu.edu/cpr

https://ulrichfrey.eu/en/niis/

http://www.ifriresearch.net/resources/data/ 
Table 3. (A) The main sectors being focused on. The total does not equal 92, because not all papers focus on a specific sector. (B) The types of articles being published. (C) The data sources used for research.

\begin{tabular}{lllll}
\hline \hline (A) Sectors of focus & $\begin{array}{l}\text { No. of } \\
\text { articles }\end{array}$ & (B) Types of articles & $\begin{array}{l}\text { No. of } \\
\text { articles }\end{array}$ & (C) Data sources \\
\hline Fisheries/marine/coastal & 39 & Empirical - single case & 46 & Secondary data \\
Forestry & 16 & Conceptual/method/theoretical & 22 & Primary and secondary \\
Irrigation/agriculture & 10 & Empirical - multiple cases & 12 & Primary \\
Watershed management & 2 & Metaanalysis/comparative analysis & 12 & 25 \\
\hline
\end{tabular}

Partelow 2015, Partelow and Boda 2015, Guevara et al. 2016, Oviedo and Bursztyn 2016, Blythe et al. 2017, London et al. 2017, Nakandakari et al. 2017, Partelow et al. 2018a) and forestry (Fleischman et al. 2010, Oberlack et al. 2015, Davenport et al. 2016). However, use of the framework has expanded beyond those resource-use sectors to general food production systems (Marshall 2015), aquaculture systems (Partelow et al. 2018b), terrestrial conservation and rangeland management (Falk et al. 2012, Risvoll et al. 2014, Baur and Binder 2015, Addison and Greiner 2016, Taggart-Hodge and Schoon 2016, Yandle et al. 2016, Guariguata et al. 2017), watershed management (Madrigal et al. 2011, Bal et al. 2011, Nagendra and Ostrom 2014, Villamayor-Tomas et al. 2014, Bennett and Gosnell 2015, Naiga et al. 2015, Silva et al. 2015, Falk et al. 2016, Hileman et al. 2016), marine conservation and marine ecosystem management (Cinner et al. 2012, Schlüter et al. 2013, Stevenson and Tissot 2014, Ban et al. 2015, 2017, Williams and Tai 2016), coastal development (Kanwar et al. 2016, Schlüter et al. 2019), energy systems (Ye 2014, Bauwens et al. 2016), and pollution management (Amblard 2012, Epstein et al. 2014b).

Substantial portions of the SESF literature are focused on smallscale CPR systems, dominated by fisheries and marine and coastal systems (Table 3). Still, many articles focus on forestry and irrigation systems, following the history of commons scholarship (Meinzen-Dick et al. 2002, Wollenberg et al. 2007). Single case study research is the most common type of analysis, followed by a considerable number of papers focused on the framework's continued development, either conceptually, methodologically, or for building theory. However, a large majority of research with the SESF relies on secondary data or a mix of primary and secondary data.

The most recent version of the SESF from McGinnis and Ostrom (2014) contains 56 second-tier variables (Table 1); however, not all variables are equally focused on or analyzed in the literature. Figure 2 compares the frequency at which each second-tier variable is explicitly included as part of an analysis or application of the framework across the literature. Social system variables (i.e., Gov. and Actor tiers) are more frequently focused on compared with ecological system variables (i.e., RS and RU tiers). The remaining variables (i.e., S, I, O and ECO tiers) receive considerably less focus comparatively. When this is further divided into focus on different resource-use sectors, the trend remains the same; there is a general disproportionate focus on social system variables (Table 4). The variety of indicators and/or definitions used for all second-tier variables, aggregated from the literature, are provided in Appendix 1 .
Fig. 2. The frequency of second-tier variables that have been focused on, either conceptually or empirically, across all relevant articles.

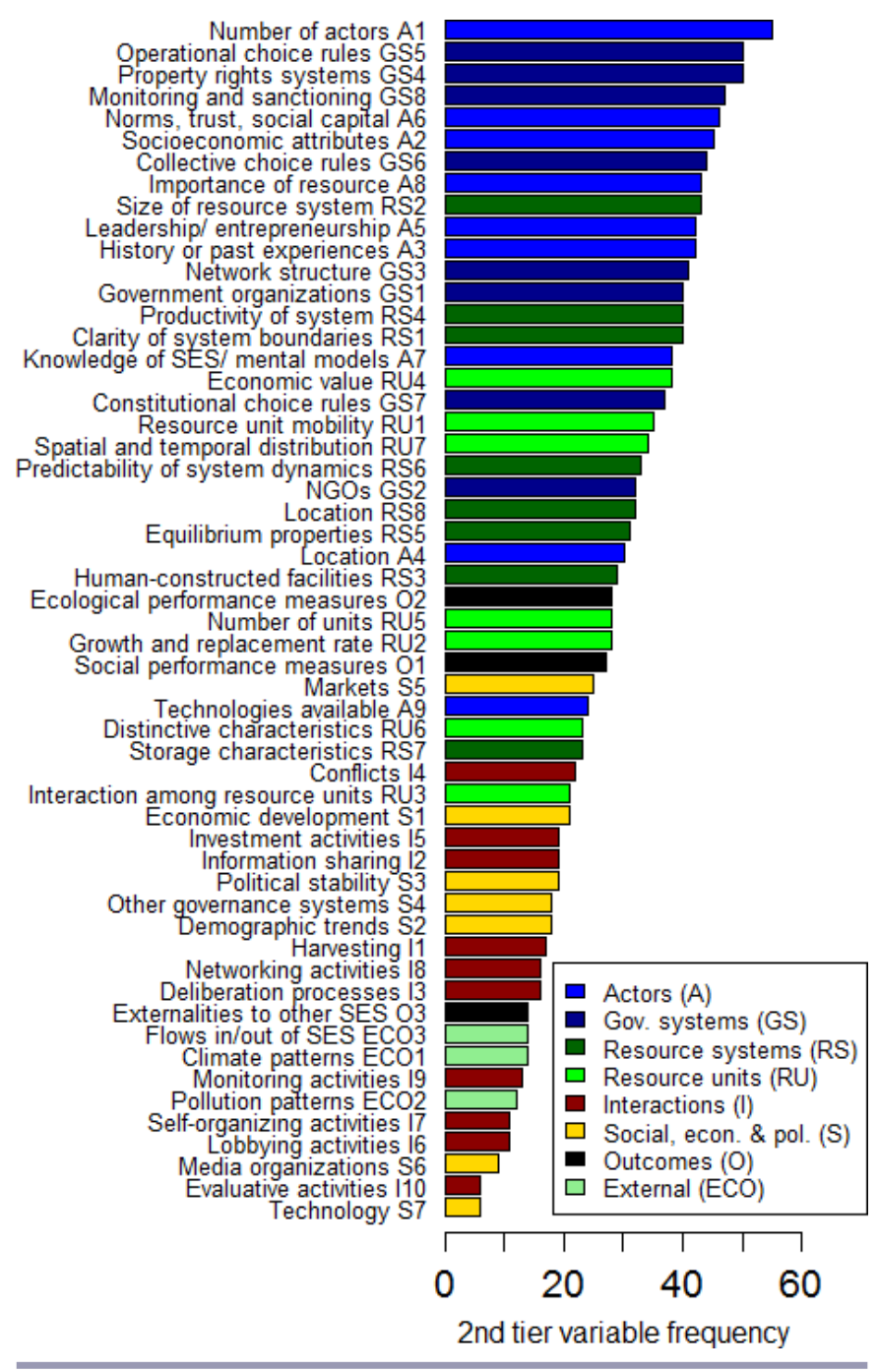

Suggested modifications to variables in the framework

Ostrom $(2007,2009)$ iterates that the framework will need to be adapted to context and further developed as new empirical analysis 
Table 4. First-tier variable frequency of all articles. "All" shows the sum of second-tier variables at the first tier from Fig. 2. "All" includes all types of articles. The sum total of "All" is then subdivided by those articles that have an empirical focus in major sectors. The total number of articles with an empirical focus is shown, followed by the sum of empirical totals in each of the most relevant sectors

\begin{tabular}{|c|c|c|c|c|c|c|c|}
\hline \multirow[t]{2}{*}{ First-tier variables } & \multicolumn{7}{|c|}{ Sum frequency of second-tier variables } \\
\hline & $\begin{array}{l}\text { Total all } \\
\text { papers }\end{array}$ & $\begin{array}{l}\text { Total empirical } \\
\text { only }\end{array}$ & Fisheries & Forestry & Irrigation & Water management & Other \\
\hline (A) Actors & 365 & 247 & 126 & 35 & 15 & 27 & 44 \\
\hline (GS) Governance & 341 & 216 & 101 & 34 & 14 & 24 & 43 \\
\hline (RS) Resource system & 271 & 206 & 101 & 33 & 15 & 22 & 35 \\
\hline (RU) Resource units & 207 & 165 & 77 & 26 & 12 & 23 & 27 \\
\hline (S) Social, economic, political & 116 & 94 & 44 & 13 & 0 & 14 & 23 \\
\hline (I) Interactions & 150 & 130 & 52 & 27 & 12 & 18 & 21 \\
\hline (O) Outcomes & 69 & 55 & 26 & 9 & 6 & 8 & 6 \\
\hline (ECO) External ecosystems & 40 & 37 & 17 & 6 & 0 & 6 & 8 \\
\hline
\end{tabular}

supports the identification of new and/or more refined variables at the second, third, and subsequent tiers. Many articles have since suggested modifications, i.e., the addition, subtraction, or modification of variables. Table 5 presents a synthesis of the literature that has suggested modifications. The degree of generalizability is different between articles, as many may only be relevant to specific contexts (e.g., fisheries or forestry). Furthermore, many articles do not make a distinction between what constitutes a new variable vs. an indicator for measuring a variable. There is a difference between developing indicators to measure second-tier variables vs. developing nested subconcepts of a variable at the third tier (see discussion on methodological gaps). Similarly, not all second-tier variables are defined in the same way across contexts, and often definitions are not explicitly stated. Some second-tier variables represent very broad concepts such as "Socioeconomic attributes (A2)," "Social performance measures (O1)," "Ecological performance measures (O2)," and "Equilibrium properties (RS6)." These variables have more suggested modifications to refine them at the third tier (see Table 5 and Appendix 1). Similarly, some variables combine multiple concepts such as "Norms (trust-reciprocity)/ social capital (A6)," "Knowledge of SES/ Mental models (A7)," "Leadership/ entrepreneurship (A5)," "History or past experiences (A3)," "Monitoring and sanctioning (GS8)," and "Spatial and temporal distribution (RU7)." These variables have also received multiple suggested modifications.

\section{Types of research applying the social-ecological systems framework}

The SESF can be used as a tool for different types of research. Table 6 provides an overview of six types of research in which the framework has been applied. These include (1) conducting a mixed-method diagnosis of a single case study, (2) conducting a qualitative diagnosis of a single case study, (3) conducting a quantitative diagnosis of a single case study, (4) conducting a metaanalysis of the literature, (5) comparative analysis diagnosing multiple case studies, or a large $\mathrm{N}$ comparative analysis (using either of the first three types), and (6) using the framework as a deliberation tool. The general purpose of each type of research, the benefits of using the SESF, potential challenges, and related literature are provided in Table 6 . A few articles have additionally explored modeling approaches linked to the categories in Table 6 (Frey and Rusch 2013; Schlüter et al. 2014)

\section{DISCUSSION}

This discussion focuses on the current methodological challenges for applying the SESF and challenges for its continued modification by reflecting on the results above. Current trends in the literature help to spotlight many existing challenges, motivating numerous discussion points on how these trends stem from the framework's history, indicating the importance of considering how the framework is situated epistemologically. This discussion attempts to guide future research with the SESF by summarizing some of the methodological challenges (which are general in nature, but nonetheless important for applying the framework), and to signpost where to look in the literature for additional insights. To start, the results above are briefly discussed along with reflection into why certain trends may exist. This is followed by discussion of the challenges for modifying the framework. The remainder of the paper focuses on specific methodological gaps for applying the SESF and discusses whether the framework has made progress in helping achieve some of the goals it was claimed to be useful for (Ostrom 2007, 2009). In the conclusion, future research trajectories are discussed.

\section{Social-ecological systems framework research trends and methodological challenges}

Social-ecological systems framework research remains largely focused on small-scale CPR systems and public goods, similar to the majority of research in commons scholarship (Meinzen-Dick et al. 2002, Wollenberg et al. 2007). Similarly, case studies remain focused on the "classic" CPR systems of fisheries, forestry, and irrigation systems. There is certainly room to expand the scope of where the SESF is applied beyond these classic commons and beyond small-scale systems. This review is not an overview of all commons scholarship, just those applying the SESF, but it nonetheless shows the tight link between the two and some current trends. It has long been assumed that knowledge generated on small-scale CPR systems is to a large extent generalizable. This claim can be further tested with more applications of the SESF to diverse cases. A few papers have recently begun to shift the focus to large-scale commons (Cox 2014b, Epstein et al. 2014a, Ban et al. 2015, 2017) and hybrid or overlapping commons like coastal systems (Schlüter et al. 2019) and pond aquaculture (Partelow et al. 2018b).

Perhaps the most interesting trend is the extensive use of secondary data. This may be occurring for numerous reasons. 
Many authors are simply reanalyzing existing data, using the SESF as a conceptual tool to reframe, restructure, or integrate existing data for new analysis. This also suggests that many scholars are revisiting existing case studies to provide a new conceptual lens. The combination of primary and secondary data is common and is likely a result of the difficulties in collecting sufficient primary data on all the relevant second-tier variables in a case study. If scholars are returning to previous case studies, it is likely that previous data exist. However, very few studies are looking at temporal changes within cases, where there is room for future research. In addition, metaanalysis studies are using secondary data as well as many comparative analysis studies. Nonetheless it is evident that many scholars find it difficult to design empirical research approaches using the SESF from scratch. There are substantial methodological challenges with applying the SESF to a new case study, such as the meaning of a tiered framework, familiarity with collective action literature, understanding diagnostic methodologies, as well as analyzing nested social and ecological systems in an integrated way, as well as how outcome variables relate to other variables in the framework (Hinkel et al. 2014). These likely explain why relatively few articles use primary data. Primary empirical data collection guided by the SESF involves considerable methodological attention to detail, particularly for the design and implementation of empirical data collection. Familiarity with framework's history and multidisciplinary knowledge on the potential relevance of second-tier variables in a case study are critical. Studies that reanalyze existing data do not have this difficulty to the same extent with data collection, but have many substantial challenges with understanding the data collection methods of previous studies, data formatting, and analysis. A main challenge with secondary data is that it typically involves some sort of data coding procedure (Ratajczyk et al. 2016). This might explain why the framework is a useful conceptual tool but is less applied empirically due to a lack of methodological knowledge or guidance on how to do so.

\section{Modifying the social-ecological systems framework variables}

Many have argued for the need to modify variables in the SESF, given new empirical analysis of more diverse cases. For example, numerous articles have suggested modifications to include more biophysical variables (e.g., Epstein et al. 2013, Vogt et al. 2015), suggesting a bias toward social system variables. This review confirms that this bias exists. This is most likely due to the development and almost exclusive use of the framework by social scientists. However, when suggesting modifications, a key question needs to be asked in relation to epistemological congruence (i.e., what theory is supporting the modification or inclusion of variables and does it align with how variables were included historically?). Below I discuss whether this is important or not. The framework does have a history that justified the inclusion of variables into a theoretical framework because they were shown to influence collective action. However, if variables are being modified for a reason other than their influence on collective action, there is a conflict with congruence in the framework's development. This is not inherently problematic; it seems likely that the SESF may take numerous developmental trajectories as it becomes useful for different purposes. However, difficulties and confusion in the literature may arise when explicit distinctions are not made between differing goals across the many papers that are applying the framework. For example, are variable modifications being suggested because they have been shown to influence collective action (i.e., building a theoretical framework of collective action for commons governance), or because they help better characterize a case study as a SES (i.e., building a theoretical/ conceptual framework of general SES)?

This issue arises due to a problem in the logic of how the SESF should continue developing (i.e., the organization and addition of variables) without explicit theoretical inclusion criteria for new variables (i.e., all studies should be grounded in collective action theory). It is clear that a large majority of research using the framework engages with collective action theories. However, it is also clear that many studies do not focus on collective action, and that knowledge on collective action theory is not necessary for the SESF to be a useful research tool in the general SES literature. Social-ecological systems framework literature suggests that the framework is useful for characterizing a system as a SES, and for diagnosing general challenges for sustainability. These applications have shown that an analysis with the SESF does not have to be related to the collective action theory roots of the framework. Nonetheless, there are also clear benefits of having a malleable framework, as envisioned by Ostrom. This makes it appealing to a broader research audience and can allow for the development of new theory using the framework's variables as the building blocks.

From the argument above, it becomes clear that the SESF does not provide a list of all relevant intrinsic variables and interactions in a social or ecological system (i.e., the SESF is not a comprehensive framework characterizing all identifiable variables and interactions in a SES). Certainly there would be more variables if there were no limitations for adding variables based on theoretical inclusion criteria. In contrast, from a social science perspective, it may be argued that all variables likely affect collective action processes in some way, or it would at least be difficult be parse out that a variable is not influential in an observational study (nearly all applications of the SESF), and that the argument for including new variables may be leveraged more on the degree of observable or explicit influence and the degree of empirical support across studies. However, it is also evident in the literature that many variable modifications are not being suggested with explicit justification as to the relevance of new or modified variables insofar as they may have a causal claim associated with them for how they affect collective action processes. Perhaps broader theoretical inclusion criteria, beyond collective action processes, could be related to a more general SES theory. Variables would then be included if causal interactive effects can be shown between new and existing variables that interdependently influence joint social-ecological outcomes more generally. This would broaden the theoretical scope of inclusion criteria, but would alter the historically consistent development of the framework thus far. This debate should find roots in future research.

This raises a second point. It is important to recognize how the framework's theoretical history has shaped its development (i.e., collective action, CPR theory, institutional analysis). This history has implications for how we view a SES with the framework and how we interpret the concept of sustainability. What is worth knowing about a SES, from an Ostromian perspective, is how 
Table 5. Articles suggesting modifications to variables of the social-ecological systems framework. The table is organized by the variables, articles, and context. Many articles suggest modifications, however, this is not an exhaustive list. Most articles focus on many variables, but only suggest modifications to a few. "All" refers to all second-tier variables within the first-tier variable.

\begin{tabular}{|c|c|c|c|}
\hline First tier & Variables & Article & Context \\
\hline \multirow{2}{*}{$\begin{array}{l}\text { Social, economic, and political } \\
\text { settings }(S)\end{array}$} & All & Delgado-Serano and Andres Ramos 2015 & Water; Forestry; Fisheries \\
\hline & $\begin{array}{l}\text { Economic development } \\
\text { Political stability }\end{array}$ & Guevarra et al. 2016 & Fisheries \\
\hline \multirow[t]{7}{*}{ Resource systems ( $R S$ ) } & All & Vogt et al. 2015 & Forestry \\
\hline & Ecological rules & Epstein et al. 2013 & Lake systems; \\
\hline & & Vogt et al. 2015 & Forestry \\
\hline & Clarity of system boundaries & Delgado-Serano and Andres Ramos 2015 & Water; Forestry; Fisheries \\
\hline & Equilibrium properties & & \\
\hline & Storage characteristics & Basurto et al. 2013 & Benthic fisheries \\
\hline & Productivity of system & Basurto et al. 2013 & Benthic fisheries \\
\hline \multirow[t]{11}{*}{ Resource units ( $R U)$} & All & Vogt et al. 2015 & Forestry \\
\hline & Resource unit mobility & Partelow and Boda 2015 & Fisheries \\
\hline & Economic value & Bennett and Gosnell 2015, Vogt et al. 2015, Delgado-Serano & PES $^{\dagger}$; Forestry \\
\hline & & and Ramos 2015 & Water; Fisheries \\
\hline & & Partelow and Boda 2015 & \\
\hline & Number of units & Partelow and Boda 2015 & Fisheries \\
\hline & Interactions among resource units & Basurto et al. 2013 & Benthic fisheries \\
\hline & Spatial and temporal distribution & & \\
\hline & & Partelow and Boda 2015; Basurto et al. 2013 & \\
\hline & Distinctive characteristics & Partelow and Boda 2015 & Fisheries \\
\hline & & Basurto et al. 2013 & Benthic fisheries \\
\hline \multirow[t]{10}{*}{ Governance systems ( $G S$ ) } & All & McGinnis and Ostrom 2014 & General \\
\hline & & Basurto et al. 2013 & Benthic fisheries \\
\hline & & Partelow and Boda 2015 & Fisheries \\
\hline & Rules-in-use & Blanco 2011 & Tourism \\
\hline & Governmental organizations & Delgado-Serano and Andres Ramos 2015 & Water; Forestry; Fisheries \\
\hline & & Williams and Tai 2016 & MPAs $^{*}$ \\
\hline & Nongovernmental organizations & Williams and Tai 2016 & MPAs \\
\hline & Network structure & Delgado-Serano and Andres Ramos 2015 & Water; Forestry; Fisheries \\
\hline & Property-rights systems & Delgado-Serano and Ramos 2015 & Water; Forestry; Fisheries \\
\hline & Monitoring and sanctioning & Delgado-Serano and Andres Ramos 2015 & Water; Forestry; Fisheries \\
\hline \multirow[t]{11}{*}{ Actors (A) } & All & Partelow and Boda 2015 & Fisheries \\
\hline & Number of relevant actors & Duff 2017 & Agriculture \\
\hline & & Delgado-Serano and Andres Ramos 2015 & Water; Forestry; Fisheries \\
\hline & Socioeconomic attributes & Bennett and Gosnell 2015 & $\mathrm{PES}^{\dagger}$ \\
\hline & & Delgado-Serano and Andres Ramos 2015 & Water; Forestry; Fisheries \\
\hline & Technologies & Duff 2017 & Agriculture \\
\hline & & Basurto et al. 2013 & Benthic fisheries \\
\hline & History and past experiences & Basurto et al. 2013 & Benthic fisheries \\
\hline & Norms/social capital & Delgado-Serano and Andres Ramos 2015 & Water; Forestry; Fisheries \\
\hline & Knowledge of SES/mental models & Delgado-Serano and Andres Ramos 2015 & Water; Forestry; Fisheries \\
\hline & Dependence & Basurto et al. 2013 & Benthic fisheries \\
\hline \multirow[t]{12}{*}{ Interactions (I) } & Harvesting levels & Delgado-Serano and Andres Ramos 2015 & Water; Forestry; Fisheries \\
\hline & Information sharing & Duff 2017 & Agriculture \\
\hline & & Delgado-Serano and Andres Ramos 2015 & Water; Forestry; Fisheries \\
\hline & Power differentials & Blythe et al. 2017 & Fisheries \\
\hline & Deliberation processes & Duff 2017 & Agriculture \\
\hline & & Delgado-Serano and Andres Ramos 2015 & Water; Forestry; Fisheries \\
\hline & Conflicts & Duff 2017 & Agriculture \\
\hline & & Delgado-Serano and Andres Ramos 2015 & Water; Forestry; Fisheries \\
\hline & Monitoring activities & Bennett and Gosnell 2015 & $\mathrm{PES}^{\dagger}$ \\
\hline & Investment activities & Bennett and Gosnell 2015 & $\mathrm{PES}^{\dagger}$ \\
\hline & Networking activities & Delgado-Serano and Andres Ramos 2015 & Water; Forestry; Fisheries \\
\hline & (Cross level application) & Oberlack et al. 2015 & Forestry \\
\hline \multirow[t]{5}{*}{ Outcomes $(O)$} & Social outcomes & Duff 2017 & Agriculture; \\
\hline & & Blythe et al. 2017 & Water; Forestry; Fisheries \\
\hline & & Delgado-Serano and Andres Ramos 2015 & \\
\hline & Ecological outcomes & Duff 2017 & Agriculture \\
\hline & & Delgado-Serano and Andres Ramos 2015 & Water; Forestry; Fisheries \\
\hline External ecosystems (ECO) & Pollution patterns & Duff 2017 & Agriculture \\
\hline
\end{tabular}


Table 6. Approaches for applying the social-ecological systems framework for different types of research

\begin{tabular}{|c|c|c|}
\hline Type of research & Purpose, benefits $(+)$ and challenges (-) & Example literature \\
\hline $\begin{array}{l}\text { (1) Mixed method } \\
\text { diagnosis or } \\
\text { characterization of a case } \\
\text { study }\end{array}$ & $\begin{array}{l}\text { Purpose: Comprehensive analysis of a case study } \\
\text { (+) Comprehensive and more holistic analysis } \\
\text { (+) Most robust type of case study analysis } \\
\text { (+/-) Multidisciplinary knowledge and/or team needed } \\
\text { (+/-) Multiple types of data generated } \\
(-) \text { Data integration, transformation, and analysis can be difficult } \\
(-) \text { Extensive field work/data collection period }\end{array}$ & $\begin{array}{l}\text { Ernst et al. 2013, Cox 2014a, } \\
\text { Barnett and Eakin 2015, } \\
\text { Guevara et al. 2016, } \\
\text { Partelow et al. } 2018 b\end{array}$ \\
\hline
\end{tabular}

(2) Qualitative diagnosis or Purpose: Focused analysis of a case study characterization of a case $(+)$ Potential for indepth analysis of social system study

$(+)$ Discursive understanding

(+/-) Qualitative data analysis techniques

(-) Potential lack of data on ecological system if no secondary data

(-) Smaller N sampling potential

(3) Quantitative diagnosis or characterization of a case study

(4) Metaanalysis of the literature

(5) Comparative analysis of case studies/large $\mathrm{N}$

(6) As a deliberation tool
Purpose: Focused analysis of a case study

$(+)$ All variable measurements quantified and comparable

$(+)$ Larger $\mathrm{N}$ sampling potential

(+/-) Statistical data analysis techniques

(-) Difficult to develop quantifiable indicators to measure all variables

(-) Lack of discursive elements

(-) Potential difficulties in access to needed data or sampling

(-) Potential loss of depth by quantification of complex variables

Purpose: Empirical or discursive synthesis of secondhand literature, case studies, or data to advance theory, concepts, or the characterization of a field of study

(+) Synthesis across contexts with common framework

(+) Increased comparability of findings

(-) Lack of access to primary data/data abstraction

(-) Difficulties integrating data

Purpose: Empirical comparison or synthesis of typically firsthand data to advance theory, concepts, or characterization of a field of study

(+) Provides a structure and variables for comparison

(-) Finding common definitions which apply across cases

(-) Data often abstracted out of context

Purpose: Transform SESF into a tool to facilitate deliberation or deliberative processes

(+) Applied use of framework

(+) Knowledge exchange within and between actor groups

(-) Transformation of SESF to a contextually understandable form
Ban et al. 2015, Hoogesteger 2015, Naiga et al. 2015, Oberlack et al. 2015, London et al. 2017

Hearn 2008, Madrigal et al. 2011, Leslie et al. 2015, Sharma et al. 2016

Blanco 2011, Stevenson and Tissot 2014, Kelly et al. 2015, Thiel et al. 2015, Mahon et al. 2017

Gutiérrez et al. 2011, Cinner et al. 2012, Oberlack et al. 2016, Rahimi et al. 2016, Ban et al. 2017

Partelow et al., in review different parts of the system influence cooperation and resourceuse behavior through the development of institutions for commons governance. Sustainability, from this perspective, is arguably the development and maintenance of contextually appropriate institutions that can enable actors to cooperate and use resources in a way that allows for the long-term and equitable availability of those common resources. Certainly the broader concept of sustainability is not limited to this view, but it must be recognized that this creates a refined and in some ways pathdependent discourse on sustainability.

It is worth reflecting on how the manifestation of Ostrom's commons research has evolved into the SESF, and how that has shaped broader SES discourse. This leads to a critical reflection on the discourse that the SESF has created with its terminology. "Resource systems" and "Resource units" are the terminology used for biophysical variables in the framework. Similarly, Ostrom (2007, 2009) use the term "Users," which was later changed to
"Actors" in McGinnis and Ostrom (2014) to broaden the utilitarian scope of different people who influence collective action to those who do not directly utilize resources. Nonetheless, this terminology has created an anthropocentric discourse on how the SESF portrays the biophysical environment. Arguably the SESF in large part portrays the biophysical environment through a lens of economic and institutional utility. These are the most obvious examples at the first-tier level, but many other secondtier variables in the framework reflect a similar discursive lens, and it is worth acknowledging how this discourse shapes a certain social-ecological worldview.

In a separate but related terminological discussion, reference to and application of the SESF requires the use of certain practical terminology. The variables of the framework are referred to with a large variety of terms including: variables, tiers, components, processes, indicators, dimensions, concepts, interactions, elements, attributes, and system dynamics, among others. 
Fig. 3. Conceptualizing the potential evolution of the SESF. Application of the framework to case studies contributes new variables and data to specific resource-use sectors (e.g., small-scale fisheries, forestry, irrigation). Different sectors may evolve separate versions of the SESF. Commonalities between all sectors contribute to the development of the general framework. Theory building may follow a similar path. General theory building across sectors would be informed by cross-sectoral commonalities.

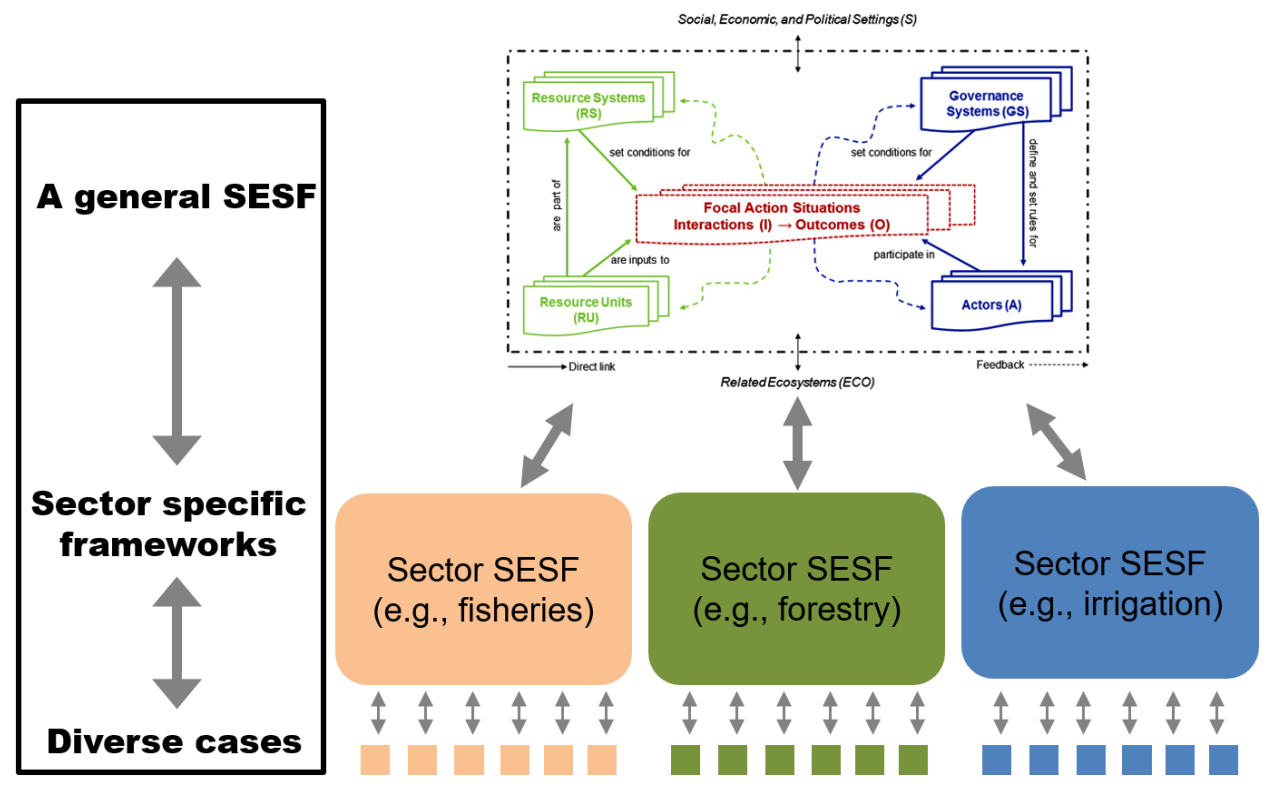

Although inconsistent terminology when referring to the firstand second-tier variables is not inherently problematic, it may create confusion or a lack of clarity in the literature and in the interpretation of findings, particularly confusion between variables and indicators. This may stem from the lack of clarity and clear definitions for many of the second-tier variables. Some are well-defined and nuanced whereas others represent broader concepts that often need further refinement or defining in the context. Not all of the second-tier variables are created equal in this way and may require modification as the framework evolves.

Many articles have suggested variable modifications (see Table 5). This is an inevitable progression as more empirical analysis emerges. However, reflection is warranted on whether suggested variable modifications are actually new variables (i.e., nested concepts meeting theoretical and ontological inclusion criteria) or are indicators for measuring a variable (i.e., empirically measurable phenomena). Also, what the level of generalizability of suggested modifications is in relation to other cases and sectors. It is evident that separate frameworks are likely to evolve for use in specific sectors because many relevant variables in specific sectors may not be generalizable (Fig. 3) e.g., (Basurto et al. 2013, Marshall 2015, Partelow and Boda 2015). The role of some variables is likely to be unique to certain sectors. However, the relationship between potential specialized frameworks for specific sectors and a general framework cannot be made a priori. This will depend on the degree of empirical support for the specialized framework and the ability to compare data across cases with a sector, and then between sectors (Fig. 3), in coherent and methodologically rigorous ways.
As discussed above, one of the methodological difficulties is that there are no rules or guidelines for variable modifications. Frey and Cox (2015) suggest the use of a consistent ontological logic for adding new variables (i.e., structurally consistent rules for organizing variable relationships between and within tiers), such as having at least a pair of nested subconcepts that are nested under the parent variable. Having an ontological logic would certainly create consistency, but it does not address the theoretical inclusion criteria problem. Second, it is important to recognize that indicators used to measure second-tier variables are not necessarily nested subconcepts that warrant inclusion into the framework. Many articles do not make this distinction. For example, Partelow and Boda (2015) suggest a substantially modified framework that is specific to lobster fisheries but they do not make a clear distinction between what modifications are nested subconcepts of potentially new variables, and which are indicators for simply measuring the parent variable. They also do not follow a clear ontological logic. The review in this article supports conclusions from Thiel et al. (2015) that most applications and modifications to the framework remain unstructured in similar ways and are largely scattered in their attempt to jointly improve the framework with cohesive rules or inclusion criteria for new or modified variables. Future research and discussion could focus on this issue.

For further guidance on logical criteria for expanding the SESF in a cohesive way, recommendations are provided by Frey and Cox $(2015: 14)$ as a starting point. These include developing tiers and variables with meaningful relationships, restrictions, or instances between classes (i.e., tiers or variables) and subclasses. In addition, guidelines for creating classes and subclasses with 
meaningful relationships between them may include rules such as do not create singular subvariables, too many subvariables, and creating similar or reciprocal classes with related relationships to the parent variable. In reflecting on methodological challenges outlined above, four aspects are useful to consider when suggesting modifications to the framework in the future. (1) Is there a structural or ontological consistency when making modifications? (see Frey and Cox, 2014:14). (2) What is the empirical evidence for any modifications (e.g., case studies or metaanalysis)? (3) What are the theoretical inclusion criteria? (4) To what degree of generalizability do the modifications apply: to all systems or only to a specific resource-use sector (e.g., fisheries, forestry)?

A final point on modifications is warranted on the "Interactions (I)" variables of the SESF and how they relate to the Institutional Analysis and Development (IAD) framework (Ostrom 2005, McGinnis 2011). It is unclear whether applications of the framework in the literature retain the original idea of the "action situation" when relating to the "Interactions (I)" variables, because most of the literature applying the SESF does not refer to the IAD framework or action situations. These variables arguably have the strongest theoretical link to institutional change and collective action theories. However, they are also some of the least focused on second-tier variables despite their central placement (Fig. 1). This may be related to a lack of knowledge about their theoretical origin as the framework has gained a wider audience.

Perhaps "interactions" could evolve into archetypes (e.g., Oberlack et al. 2016), typologies (e.g., Alessa et al. 2009), or bundles of interacting second-tier variables (e.g., Partelow et al. $2018 a$ ) from the other tiers. This could be viewed as a process of building a general theory of SES interactions similar to how property rights and biophysical traits are often interpreted as interacting bundles or commonly associated system characteristics with repeating patterns of variable interactions and outcomes. Emerging SES theory could be viewed in this way, by attempting to identify commonly associated and interacting variables in the SESF. For example, a social-ecological trap (Boonstra and De Boer 2014) may be a common archetype or bundle of interacting variables with certain values that could be identified with the SESF variables (e.g., High dependence (A8); Low value (RU4); Low socio-economic conditions (A2); Declining resources (RU5)), and could be empirically observed as leading to largely repeatable outcomes (i.e., Decreasing livelihood security $(\mathrm{O} 1)$ and resource degradation $(\mathrm{O} 2)$ ). Thus, a social-ecological trap could be an example of an archetype of interactions that is part of a general SES theory using the frameworks variables. Use of the "Interactions (I)" variables in this way would alter the original aim of the framework beyond collective action theories (particularly beyond the IAD framework) to general SES theories, but may enhance their usefulness as variables and make this aspect of the framework more generally applicable to diverse cases.

The most important interactions shaping SES outcomes (not referring to the Interactions (I) variables, but general system interactions to be analyzed) may be among variables between tiers rather than within tiers of the framework. Expanding empirical analysis toward building SES theory that accounts for interacting variables across tiers can make progress toward redefining what a resource "system" or governance "system" comprises, beyond existing discursive or disciplinary conceptualizations. If interactions between variables are a primary defining characteristic for the degree to which variables are considered part of a system, the discourse on such systems will necessarily shift toward bundles or typologies of interacting variables, as well as how "interactions" in the SESF are viewed as an analytical tool for building SES theory.

\section{Applying the social-ecological systems framework: methodological gaps and challenges}

There are no general methods, guidelines, or procedures for applying the SESF, although numerous articles have provided conceptual guidance (e.g., Hinkel et al. 2015, Partelow 2016) and case examples. However, there is lack of reflection between the different papers that make explicit suggestions regarding the benefits and challenges of different methods. There is no right or wrong way to apply the framework. The variables can be defined, modified, and measured, as needed, in different contexts (Ostrom 2007, 2009). However, this has led to substantial heterogeneity in how the framework's variables are applied, relating to definitions, indicators for measurement, and modifications. Furthermore, multiple data collection and analysis methods are often used. The discussion below highlights the lessons and reflections learned across the literature and from experience applying the framework. Numerous "methodological gaps" are described below that may be useful to consider. These gaps are not unique to the framework, they relate to general scientific methodologies more broadly, but are explicitly applicable and relevant for applying the SESF.

\section{Variable definition gap}

Many variables are not well defined and/ or can have multiple meanings or interpretations when viewed in different contexts. If common definitions of variables and concepts are not used across cases, additional layers of abstraction will hinder the ability for synthesis and comparison. However, there is a trade-off here between specificity and generalizability, as it is often necessary to define variables differently across contexts. For example, the concept of social capital (A6) is not well defined and can vary in meaning across contexts. Social capital may refer to the structure, connectedness, and types of exchanges in a social network (Pretty 2003, Borgatti et al. 2009), or it may refer to degrees of trust, reciprocity, and prosocial or antisocial behavior in a group (Gutiérrez et al. 2011, Basurto et al. 2016). Definitions can dictate what will be measured and the theoretical conclusions drawn from that data about the role of that variable in a system. Many other variables in the framework create similar challenges because they are defined and measured differently, compromising the ability for comparison if definitions are not transparent to readers or those conducting synthesis research.

\section{The variable-to-indicator gap}

The variable-indicator gap refers to which indicators are selected to empirically measure or code variables. Many variables are broad concepts that are not directly measurable or easily defined, such as socioeconomic attributes (A2), norms, trust and social capital (A6), resource unit value (RU4), equilibrium properties (RS6), predictability of system dynamics (RS7), and outcomes $(\mathrm{O} 1 ; \mathrm{O} 2 ; \mathrm{O} 3)$. Context-specific indicators are often needed to measure these variables, or at least to understand a variable in context. Two studies may examine the same variable with the same 
definition, but they may select different indicators to measure them. This creates a degree of abstraction for comparative research. For example, indicators to measure actor location (A4) could be the distance between the home of an actor to the place where they access the resource system (RS) or resource units (RU), or, it could be the distance from the home to other actors or community meeting places where collective decisions are taken.

\section{The measurement gap}

The measurement gap refers to how variables or indicators are actually measured or coded. It is evident that two studies can examine the same variable, use a common definition and indicator, but still measure the variable in a different way. For example, economic value (RU4) may be defined as the market value of the resource unit, and both studies use the indicator of price per kilogram. One study may employ qualitative methods, asking individual actors (e.g., fishers) to recall the prices they received on the market over the last month by asking the fisher to explain variability and how prices are negotiated. A second study may collect quantitative data on fish sales from fish markets to establish price averages over the last 6 months. The studies may draw different conclusions on the economic value of the resource and the role that market variability has on system dynamics.

\section{Data transformation gap}

The data transformation gap refers to how raw data are transformed into usable or presentable data in an analysis, graphic or written text form. Or, how published data are recorded or transformed from literature review or metaanalysis for additional analysis. Transforming data into different structures (e.g., continuous, ordinal, categorical, text) is often necessary to conduct an integrated or comparative analysis. Many different data types have been used to analyze the variables and their interactions in the SESF. Data transformation can enhance comparability but also compromises meaning and context. For example, raw qualitative interview data may be coded, synthesized, and transformed into ordinal data (e.g., low, medium, high) for further analysis or presentation. Methodological transparency becomes of high importance for interpreting findings, for all the "gaps" above. This problem occurs in both qualitative and quantitative research. Different studies will inevitably use different transformation methods, stressing the need for transparency.

\section{CONCLUSION}

Future research with the social-ecological systems framework Much of the above discussion provides insights into future research considerations given the trends in the literature. However, a few explicit points can act as a more general set of concluding remarks for future research related to the framework's general aims. Ostrom $(2007,2009)$ argued that the SESF could provide numerous benefits for scholars, including (1) a general framework that could be adapted and applied to diverse cases, (2) a core set of variables and a common language to better enable comparison and communication, as well as (3) a diagnostic tool, potentially enabling new theories to be developed through analysis of interlinkages between variables and outcomes. Each is briefly discussed below as to how future research may be able to make progress toward achieving them.

\section{(1) A general but adaptable framework}

The framework can be tailored to context by modifying the definitions of variables, indicators to measure them, data collection, and analysis methods. As a result, the framework can be, and has been, applied to a wide variety of cases. This is arguably its strong point. However, it is also clear from this study that applying the framework has led to many suggested modifications to variables. Some articles suggest more generalizable modifications (McGinnis and Ostrom 2014), some for use in specific sectors (Table 5). It appears that the general framework will evolve, but specific frameworks will also evolve for use in specific sectors (e.g., small-scale fisheries, forestry, and irrigation). Following the guidelines in the "methodological gaps" discussion section and those provided by Frey and Cox (2015), future research can find useful recommendations for addressing some of the challenges stemming from a lack of cohesion in how the framework is adapted and modified for use in diverse cases (i.e., data comparability) while maintaining the ambition to continue advancing a general framework.

Figure 3 conceptualizes this potential future research process. An intermediary step may be the development of sector-specific frameworks (e.g., for fisheries, irrigation, forestry) that can help bridge the gap between diverse but related case studies and a general framework. Sector-specific frameworks, which would add, develop, and define new or existing variables of the framework within the scope of a sector (e.g., small-scale fisheries), could contribute to evolving a general framework after modifications are empirically assessed for their degree of generalizability. Methodological transparency is essential for future research addressing the "methodological gaps" and attempting to adhere to the suggested guidelines for variable modifications. Sectorspecific frameworks could help avoid confusion between the many diverse studies that apply the framework and allow more robust comparison between similar cases before attempting more abstract comparisons between cases where the social and ecological conditions may be less similar. Degrees of generalizability could be assessed between similar cases within sectors before abstracting their potential generalizability to the general framework. Overlapping commonalities could then more robustly inform a general framework (which would remain the pillar for collective action theory across contexts). Additional theory (beyond collective action) could include the development of interacting bundles, typologies, or archetypes of social-ecological interactions discussed above that lead to empirically identifiable and patterned outcomes across cases using the framework's variables as theoretical building blocks; this is discussed further below.

\section{(2) Enabling comparison}

The literature applying the SESF is heterogeneous, and it is unclear the extent to which the empirical data can be compared across cases in a meaningful way without substantial recoding, transforming, or simplifying heterogeneous data. A key step for future research will be increased methodological transparency in the use of research design for primary data collection and the use of secondary data by considering the "methodological gaps" discussed above. Without general but clear guidelines, a metaanalysis of empirical case studies would currently be a monumental effort to overcome methodological blind spots and integrate data, and with current SESF studies, provide largely unreliable data given the high degrees of heterogeneity in data 
collection methods, context, and system scales examined in the literature. A few studies have been successful with large comparative studies, but they have largely relied on highly systematized primary data collection on common variables controlled by the authors e.g., (Cinner et al. 2012, Leslie et al. 2015) or substantial secondary data mining and coding efforts e.g., (Gutiérrez et al. 2011, Oberlack et al. 2016, Rahimi et al. 2016). Either way, successful comparative studies are made easier when the data available were collected with the intention to be compared. However, many individual case studies are not designed to be compared with other cases within or between sectors, and efforts to do so without methodological transparency would likely draw highly abstracted conclusions about the empirical studies being examined.

Databases are a promising way forward for enabling comparison, where the authors of individual studies format their data themselves into shared digital repositories. This eliminates data abstraction barriers by nonauthors but also requires incentives for authors to contribute to common databases, which is a provision of the public goods collective action dilemma itself. Many of the databases presented in Table 2 are attempting to facilitate this, but their success requires largely voluntary contributions, which are encouraged by those facilitating them and recommended for scholars using the framework to engage with.

\section{(3) A diagnostic tool for theory building}

The SESF is not a theory-neutral tool. Historically, the inclusion criteria for variables were based on their influence on collective action in small-scale CPR systems. However, the generalizability of these variables seems to be broad in scope, with numerous studies using the variables to generally characterize SES or to develop other closely related theory on natural resource governance (Cox et al. 2016). It is evident that the framework's variables provide a template for expanding commons research and asking new theoretical questions about social-ecological interactions and outcomes. This has not yet been fully explored in the literature, and it remains unclear, although still promising, that the SESF can aid the process of theory development for general SES research. Perhaps future research can further explore further uses for the framework, particularly its potential to contribute to building general theories of social-ecological interactions by identifying typologies or archetypes of social-ecological interactions (Alessa et al. 2009, Oberlack et al. 2016, Partelow et al. 2018a). Integrating the framework with other conceptual and theoretical frameworks may expand its usefulness for contributing to other theories and frameworks in associated fields such as ecosystem services, sustainability science, the Coupled Infrastructure Systems framework, and resilience theory (Binder et al. 2013, Anderies et al. 2016, Partelow 2016, Partelow and Winkler 2016). This would somewhat remove the theoretical history with collective action theory in parts of the literature engaging with the framework. However, there is also recognition that collective action theory is nested within broader concepts of SES and sustainability, both of which are likely to evolve.

Responses to this article can be read online at: http://www.ecologyandsociety.org/issues/responses. php/10594

\section{Acknowledgments:}

I would like to acknowledge support from the Leibniz Centre for Tropical Marine Research (ZMT). The publication of this article was funded by the Open Access Fund of the Leibniz Association. Many thanks to the editors and three anonymous reviewers for constructive and thoughtful comments that have improved the manuscript. I am grateful for comments and discussions with Achim Schlüter and Chris Lüderitz while developing and revising this manuscript. Any remaining errors or inconsistencies are my own. Additional thanks to Vigneshwaran Soundararajan for assistance.

\section{LITERATURE CITED}

Abson, D. J., H. von Wehrden, S. Baumgärtner, J. Fischer, J. Hanspach, W. Härdtle, H. Heinrichs, A. M. Klein, D. J. Lang, P. Martens, and D. Walmsley. 2014. Ecosystem services as a boundary object for sustainability. Ecological Economics 103:2937. http://dx.doi.org/10.1016/j.ecolecon.2014.04.012

Addison, J., and R. Greiner. 2016. Applying the social-ecological systems framework to the evaluation and design of payment for ecosystem service schemes in the Eurasian steppe. Biodiversity and Conservation 25(12):2421-2440. http://dx.doi.org/10.1007/ $\underline{\mathrm{s} 10531-015-1016-3}$

Agrawal, A. 2001. Common property institutions and sustainable governance of resources. World Development 29(10):1649-1672. http://dx.doi.org/10.1016/S0305-750X(01)00063-8

Agrawal, A. 2003. Sustainable governance of common-pool resources: context, methods, and politics. Annual Review of Anthropology 32(1):243-262. http://dx.doi.org/10.1146/annurev. anthro.32.061002.093112

Alessa, L., A. Kliskey, and M. Altaweel. 2009. Toward a typology for social-ecological systems. Sustainability: Science, Practice and Policy 5(1):31-41. https://doi.org/10.1080/15487733.2009.11908026. http://dx.doi.org/10.1080/15487733.2009.11908026

Amblard, L. 2012. The potential of collective action for the control of nonpoint source pollution in European rural areas. Pages 1-19 in T. De Moor, M. Laborda Pemà, and R. van Weeren, organizers. Conference: Design and dynamics of institutions for collective action. Utrecht University, Utrecht, The Netherlands.

Anderies, J. M., M. A. Janssen, and E. Ostrom. 2004. A framework to analyze the robustness of social-ecological systems from an institutional perspective. Ecology and Society 9(1): 18. http://dx. doi.org/10.5751/ES-00610-090118

Anderies, J. M., M. A. Janssen, and E. Schlager. 2016. Institutions and the performance of coupled infrastructure systems. International Journal of the Commons 10(2):495-516. http://dx. doi.org/10.18352/ijc.651

Arlinghaus, R., J. Alós, B. Beardmore, K. Daedlow, M. Dorow, M. Fujitani, D. Hühn, W. Haider, L. M. Hunt, B. M. Johnson, F. Johnston, T. Klefoth, S. Matsumura, C. Monk, T. Pagel, J. R. Post, T. Rapp, C. Riepe, H. Ward, and C. Wolter. 2017. Understanding and managing freshwater recreational fisheries as complex adaptive social-ecological systems. Reviews in Fisheries Science and Aquaculture 25(1):1-41. http://dx.doi. org/10.1080/23308249.2016.1209160 
Aswani, S., G. G. Gurney, S. Mulville, J. Matera, and M. Gurven. 2013. Insights from experimental economics on local cooperation in a small-scale fishery management system. Global Environmental Change 23(6):1402-1409. http://dx.doi.org/10.1016/ j.gloenvcha.2013.08.003

Bal, M.B., J.A. Van Ast, and J.J. Bouma. 2011. Sustainability of water resource systems in India: role of value in urban lake governance in Ahmedabad. Department of Public Administration, Faculty of Social Sciences, Erasmus University, Rotterdam, The Netherlands.

Ban, N. C., T. E. Davies, S. E. Aguilera, C. Brooks, M. Cox, G. Epstein, L. S. Evans, S. M. Maxwell, and M. Nenadovic. 2017. Social and ecological effectiveness of large marine protected areas. Global Environmental Change 43:82-91. http://dx.doi. org/10.1016/j.gloenvcha.2017.01.003

Ban, N. C., L. S. Evans, M. Nenadovic, and M. Schoon. 2015. Interplay of multiple goods, ecosystem services, and property rights in large social-ecological marine protected areas. Ecology and Society 20(4): 2. http://dx.doi.org/10.5751/ES-07857-200402

Barnett, A. J., and H. C. Eakin. 2015. "We and us, not I and me": justice, social capital, and household vulnerability in a Nova Scotia fishery. Applied Geography 59:107-116. http://dx.doi. org/10.1016/j.apgeog.2014.11.005

Basurto, X., E. Blanco, M. Nenadovic, and B. Vollan. 2016. Integrating simultaneous pro-social and anti-social behaviour into theories of collective action. Science Advances (March):122.

Basurto, X., S. Gelcich, and E. Ostrom. 2013. The socialecological system framework as a knowledge classificatory system for benthic small-scale fisheries. Global Environmental Change 23 (6):1366-1380. http://dx.doi.org/10.1016/j.gloenvcha.2013.08.001

Baur, I., and C. R. Binder. 2015. Modeling and assessing scenarios of common property pastures management in Switzerland. Ecological Economics 119:292-305. http://dx.doi.org/10.1016/j. ecolecon.2015.09.019

Bauwens, T., B. Gotchev, and L. Holstenkamp. 2016. What drives the development of community energy in Europe? The case of wind power cooperatives. Energy Research and Social Science 13:136-147. http://dx.doi.org/10.1016/j.erss.2015.12.016

Bennett, D. E., and H. Gosnell. 2015. Integrating multiple perspectives on payments for ecosystem services through a socialecological systems framework. Ecological Economics 116:172181. http://dx.doi.org/10.1016/j.ecolecon.2015.04.019

Berkes, F., and C. Folke. 1998. Linking social and ecological systems: management practices and social mechanisms for building resilience. Cambridge University Press, Cambridge, UK.

Binder, C., J. Hinkel, P. W. G. Bots, and C. Pahl-Wostl. 2013. Comparison of frameworks for analyzing social-ecological systems. Ecology and Society 18(4): 26. http://dx.doi.org/10.5751/ ES-05551-180426

Blanco, E. 2011. A social-ecological approach to voluntary environmental initiatives: the case of nature-based tourism. Policy Sciences 44: 35. https://doi.org/10.1007/s11077-010-9121-3 http:// dx.doi.org/10.1007/s11077-010-9121-3
Blythe, J., P. Cohen, H. Eriksson, J. Cinner, D. Boso, A.-M. Schwarz, and N. Andrew. 2017. Strengthening post-hoc analysis of community-based fisheries management through the socialecological systems framework. Marine Policy 82(February):50 58. http://dx.doi.org/10.1016/j.marpol.2017.05.008

Boonstra, W. J., and F. W. De Boer. 2014. The historical dynamics of social-ecological traps. Ambio 43(3):260-274. http://dx.doi. org/10.1007/s13280-013-0419-1

Borgatti, S. P., A. Mehra, D. J. Brass, and G. Labianca. 2009. Network analysis in the social sciences. Science 323:892-895. http://dx.doi.org/10.1126/science.1165821

Cinner, J. E., T. R. McClanahan, M. A. MacNeil, N. A. J. Graham, T. M. Daw, A. Mukminin, D. A. Feary, A. L. Rabearisoa, A. Wamukota, N. Jiddawi, S. J. Campbell, A. H. Baird, F. A. Januchowski-Hartley, S. Hamed, R. Lahari, T. Morove, and J. Kuange. 2012. Comanagement of coral reef social-ecological systems. Proceedings of the National Academy of Sciences 109 (14):5219-5222. http://dx.doi.org/10.1073/pnas.1121215109

Coase, R. 1998. The new institutional economics. The American Economic Review 88(2):72-74.

Cole, D. H., G. Epstein, and M. D. McGinnis. 2014. Digging deeper into Hardin's pasture: the complex institutional structure of "the tragedy of the commons." Journal of Institutional Economics 10(3):353-369. http://dx.doi.org/https://doi.org/10.1017/ $\underline{\mathrm{S} 1744137414000101}$

Cox, M. 2014a. Applying a social-ecological system framework to the study of the Taos Valley irrigation system. Human Ecology 42(2):311-324. http://dx.doi.org/https://doi.org/10.1007/s10745-014-9651y

Cox, M. 2014b. Understanding large social-ecological systems: introducing the SESMAD project. International Journal of the Commons 8(2):265-276. http://dx.doi.org/https://doi.org/10.18352/ ijc. 406

Cox, M., S. Villamayor-Tomas, G. Epstein, L. Evans, N. C. Ban, F. Fleischman, M. Nenadovic, and G. Garcia-Lopez. 2016. Synthesizing theories of natural resource management and governance. Global Environmental Change 39(January):45-56. http://dx.doi.org/10.1016/j.gloenvcha.2016.04.011

Daily, G. C. 1997. Nature's services: societal dependence on natural ecosystems. Island Press, Washington, D.C., USA.

Davenport, R. B., P. H. May, P. Nogueira, and P. C. Nunes. 2016. A policy mix to prevent a non-commons tragedy for collective forest reserves in agrarian settlements in northwest Mato Grosso | Um mix de políticas para evitar a privatização dos recursos naturais nas reservas florestais coletivas dos assentamentos rurais. Revista de Economia Contemporanea 20(3):405-429. http://dx. doi.org/https://doi.org/10.1590/198055272032

Delgado-Serrano, M. del M., and P. Andres Ramos. 2015. Making Ostrom's framework applicable to characterise social ecological systems at the local level. International Journal of the Commons 9(2):808-830. http://dx.doi.org/10.18352/ijc.567

Duff, A. J., P. H. Zedler, J. A. Barzen, and D. L. Knuteson. 2017. The capacity-building stewardship model: assessment of an agricultural network as a mechanism for improving regional 
agroecosystem sustainability. Ecology and Society 22(1): 45. http://dx.doi.org/10.5751/ES-09146-220145

Epstein, G., M. Nenadovic, and A. Boustany. 2014a. Into the deep blue sea: commons theory and international governance of Atlantic bluefin tuna. International Journal of the Commons 8 (2):277-303. http://dx.doi.org/https://doi.org/10.18352/ijc.410

Epstein, G., I. Pérez, M. Schoon, and C. L. Meek. $2014 b$. Governing the invisible commons: ozone regulation and the Montreal protocol. International Journal of the Commons 8 (2):337-360. http://dx.doi.org/https://doi.org/10.18352/ijc.407

Epstein, G., J. M. Vogt, S. K. Mincey, M. Cox, and B. Fischer. 2013. Missing ecology: integrating ecological perspectives with the social-ecological system framework. International Journal of the Commons 7(2):432-453. http://dx.doi.org/10.18352/ijc.371

Ernst, B., J. Chamorro, P. Manríquez, J. M. L. Orensanz, A. M. Parma, J. Porobic, and C. Román. 2013. Sustainability of the Juan Fernández lobster fishery (Chile) and the perils of generic sciencebased prescriptions. Global Environmental Change 23(6):13811392. http://dx.doi.org/10.1016/j.gloenvcha.2013.08.002

Falk, T., M. Kirk, D. Lohmann, B. Kruger, and C. Hüttich. 2012. The profits of excludability and transferability in the socialecological systems of land reform in central Namibia. Conference paper. Annual World Bank Conference on Land and Poverty, 2326 2012, The World Bank, Washington, D.C., USA.

Falk, T., D. Lohmann, and N. Azebaze. 2016. Congruence of appropriation and provision in collective water provision in Central Namibia. International Journal of the Commons 10(1):71118. http://dx.doi.org/https://doi.org/10.18352/ijc.583

Fischer, J., T. A. Gardner, E. M. Bennett, P. Balvanera, R. Biggs, S. Carpenter, T. Daw, C. Folke, R. Hill, T. P. Hughes, T. Luthe, M. Maass, M. Meacham, A. V Norstrom, G. Peterson, C. Queiroz, R. Seppelt, M. Spierenburg, and J. Tenhunen. 2015. Advancing sustainability through mainstreaming a socialecological systems perspective. Current Opinion in Environmental Sustainability 14:144-149. http://dx.doi.org/10.1016/j.cosust.2015.06.002

Fleischman, F., K. Boenning, G. A. Garcia-Lopez, S. Mincey, M. Schmitt-Harsh, K. Daedlow, M. C. López, X. Basurto, B. C. Fischer, and E. Ostrom. 2010. Disturbance, response, and persistence in self-organized forested communities: analysis of robustness and resilience in five communities in southern Indiana. Ecology and Society 15(4): 9. http://dx.doi.org/10.5751/ ES-03512-150409

Flynn, C. D., and C. I. Davidson. 2016. Adapting the socialecological system framework for urban stormwater management: the case of green infrastructure adoption. Ecology and Society 21 (4): 19. http://dx.doi.org/10.5751/ES-08756-210419

Folke, C., T. Hahn, P. Olsson, and J. Norberg. 2005. Adaptive governance of social-ecological systems. Annual Review of Environment and Resources 30(1):441-473. http://dx.doi. org/10.1146/annurev.energy.30.050504.144511

Frey, U. J., and M. Cox. 2015. Building a diagnostic ontology of social-ecological systems. International Journal of the Commons 9(2):595-618. http://dx.doi.org/10.18352/ijc.505
Frey, U. J., and H. Rusch. 2013. Using artificial neural networks for the analysis of social-ecological systems. Ecology and Society 18(2): 40. http://dx.doi.org/10.5751/ES-05202-180240

Gibson, R. B. 2006. Sustainability assessment: basic components of a practical approach. Impact Assessment and Project Appraisal 24(3):170-182. http://dx.doi.org/10.3152/147154606781765147

Guariguata, M. R., P. Cronkleton, A. E. Duchelle, and P. A. Zuidema. 2017. Revisiting the 'cornerstone of Amazonian conservation': a socioecological assessment of Brazil nut exploitation. Biodiversity and Conservation 26(9):2007-2027. http://dx.doi.org/10.1007/s10531-017-1355-3

Guevara, L. E. T., A. Schlüter, and M. C. Lopez. 2016. Collective action in a tropical estuarine lagoon: adapting Ostrom's SES framework to Ciénaga Grande de Santa Marta. International Journal of the Commons 10(1):1-29.

Gutiérrez, N. L., R. Hilborn, and O. Defeo. 2011. Leadership, social capital and incentives promote successful fisheries. Nature 470(7334):386-389. http://dx.doi.org/10.1038/nature09689

Hardin, G. 1968. The tragedy of the commons. Science 162:12431248. http://dx.doi.org/10.1126/science.162.3859.1243

Hearn, A. 2008. The rocky path to sustainable fisheries management and conservation in the Galápagos Marine Reserve. Ocean and Coastal Management 51(8-9):567-574. http://dx.doi. org/10.1016/j.ocecoaman.2008.06.009

Hertz, T., and M. Schlüter. 2015. The SES-framework as boundary object to address theory orientation in social-ecological system research: the SES-TheOr approach. Ecological Economics 116:12-24. http://dx.doi.org/10.1016/i.ecolecon.2015.03.022

Hileman, J., P. Hicks, and R. Jones. 2016. An alternative framework for analysing and managing conflicts in integrated water resources management (IWRM): linking theory and practice. International Journal of Water Resources Development 32(5):675-691. http://dx.doi.org/10.1080/07900627.2015.1076719

Hinkel, J., P. W. G. Bots, and M. Schlüter. 2014. Enhancing the Ostrom social-ecological system framework through formalization. Ecology and Society 19(3): 51. http://dx.doi.org/10.5751/ ES-06475-190351

Hinkel, J., M. E. Cox, M. Schlüter, C. R. Binder, and T. Falk. 2015. A diagnostic procedure for applying the social-ecological systems framework in diverse cases. Ecology and Society 20(1): 32. http://dx.doi.org/10.5751/ES-07023-200132

Hoogesteger, J. 2015. Normative structures, collaboration and conflict in irrigation; a case study of the Píllaro North Canal Irrigation System, Ecuadorian Highlands. International Journal of the Commons 9(1):398-415. http://dx.doi.org/10.18352/ijc.521

Hunt, L. M., S. G. Sutton, and R. Arlinghaus. 2013. Illustrating the critical role of human dimensions research for understanding and managing recreational fisheries within a social-ecological system framework. Fisheries Management and Ecology 20(23):111-124. http://dx.doi.org/10.1111/j.1365-2400.2012.00870.x

Kanwar, P., C. Koliba, S. Greenhalgh, and W. B. Bowden. 2016. An institutional analysis of the Kaipara Harbour governance network in New Zealand. Society and Natural Resources 29 (11):1359-1374. http://dx.doi.org/10.1080/08941920.2016.1144838 
Kelly, R. P., A. L. Erickson, L. A. Mease, W. Battista, J. N. Kittinger, and R. Fujita. 2015. Embracing thresholds for better environmental management. Philosophical Transactions of the Royal Society B: Biological Sciences 370(1659): 20130276. http:// dx.doi.org/10.1098/rstb.2013.0276

Klein, P. G. 1999. New institutional economics. Encyclopedia of Law and Economics 1:456-489 http://dx.doi.org/10.2139/ $\underline{\operatorname{ssrn} .115811}$

Lanz, R. 2017. After the blue rush: assessment of the sustainability of recreational fisheries in Peenemünde, Germany as part of a social-ecological system. Lund University, Lund, Germany.

Leslie, H. M., X. Basurto, M. Nenadovic, L. Sievanen, K. C. Cavanaugh, J. J. Cota-Nieto, B. E. Erismang, E. Finkbeiner, G. Hinojosa-Arango, M. Moreno-Báez, S. Nagavarapu, S. M. W. Reddy, A. Sánchez-Rodríguez, K. Siegel, J. J. UlibarriaValenzuela, A. H. Weaver, and O. Aburto-Oropeza. 2015. Operationalizing the social-ecological systems framework to assess sustainability. Proceedings of the National Academy of Sciences 112(19):5979-5984. http://dx.doi.org/10.1073/pnas.1414640112

Liu, J., T. Dietz, S. R. Carpenter, M. Alberti, C. Folke, E. Moran, A. N. Pell, P. Deadman, T. Kratz, J. Lubchenco, E. Ostrom, Z. Ouyang, W. Provencher, C. L. Redman, S. H. Schneider, and W. W. Taylor. 2007. Complexity of coupled human and natural systems. Science 317(5844):1513-1516. http://dx.doi.org/10.1126/ science. 1144004

London, S., M. L. Rojas, M. M. I. Martin, F. Scordo, M. A. H. Cisneros, M. L. Bustos, G. M. E. Perillo, and M. C. Piccolo. 2017. Characterization of an artisanal fishery in Argentina using the social-ecological systems framework. International Journal of the Commons 11(1):1-69. http://dx.doi.org/10.18352/ijc.534

Lozano, A. J. G., and J. T. Heinen. 2015. Identifying drivers of collective action for the co-management of coastal marine fisheries in the Gulf of Nicoya, Costa Rica. Environmental Management 57(4):759-769. http://dx.doi.org/https://doi.org/10.1007/ s00267-015-0646-2

MacNeil, M. A., and J. E. Cinner. 2013. Hierarchical livelihood outcomes among co-managed fisheries. Global Environmental Change 23(6):1393-1401. http://dx.doi.org/https://doi.org/10.1016/ j.gloenvcha.2013.04.003

Madrigal, R., F. Alpízar, and A. Schlüter. 2011. Determinants of performance of community-based drinking water organizations. World Development 39(9):1663-1675. http://dx.doi.org/10.1016/j. worlddev.2011.02.011

Mahon, N., I. Crute, E. Simmons, and M. M. Islam. 2017. Sustainable intensification- "oxymoron" or "third-way"? A systematic review. Ecological Indicators 74:73-97. http://dx.doi. org/10.1016/j.ecolind.2016.11.001

Marshall, G. R. 2015. A social-ecological systems framework for food systems research: accommodating transformation systems and their products. International Journal of the Commons 9 (2):881-908. http://dx.doi.org/10.18352/ijc.587

McCord, P., J. D. Angelo, E. Baldwin, and T. Evans. 2016. Polycentric transformation in Kenyan water governance: a dynamic analysis of institutional and social-ecological change.
Policy Studies Journal 45(4):633-658. http://dx.doi.org/10.1111/ psj. 12168

McGinnis, M. D. 2011. An introduction to IAD and the language of the Ostrom workshop: a simple guide to a complex framework. Policy Studies Journal 39(1):169-183. http://dx.doi.org/10.1111/ j.1541-0072.2010.00401.X

McGinnis, M. D., and E. Ostrom. 2014. Social-ecological system framework: Initial changes and continuing challenges. Ecology and Society 19(2): 30. http://dx.doi.org/10.5751/ES-06387-190230

Meinzen-Dick, R. 2007. Beyond panaceas in water institutions. Proceedings of the National Academy of Sciences 104(39):15200 15205. http://dx.doi.org/10.1073/pnas.0702296104

Meinzen-Dick, R., K. V. Raju, and A. Gulati. 2002. What affects organization and collective action for managing resources? Evidence from canal irrigation systems in India. World Development 30(4):649-666. http://dx.doi.org/10.1016/S0305-750X (01)00130-9

Miller, T. R., T. D. Baird, C. M. Littlefield, G. Kofinas, F. S. Chapin, III, and C. L. Redman. 2008. Epistemological pluralism: reorganizing interdisciplinary research. Ecology and Society 13 (2): 46. http://dx.doi.org/10.5751/ES-02671-130246

Nagendra, H., and E. Ostrom. 2014. Applying the socialecological system framework to the diagnosis of urban lake commons in Bangalore, India. Ecology and Society 19(2): 67. http://dx.doi.org/10.5751/ES-06582-190267

Naiga, R., M. Penker, and K. Hogl. 2015. Challenging pathways to safe water access in rural Uganda: From supply to demanddriven water governance. International Journal of the Commons 9 (1):237-260. http://dx.doi.org/10.18352/ijc.480

Nakandakari, A., M. Caillaux, J. Zavala, S. Gelcich, and F. Ghersi. 2017. The importance of understanding self-governance efforts in coastal fisheries in Peru: insights from La Islilla and Ilo. Bulletin of Marine Science 93(1):199-216. http://dx.doi. org/10.5343/bms.2015.1087

North, D. C. 1990. Institutions, institutional change, and economic performance. Cambridge University Press, Cambridge, UK. http://dx.doi.org/10.1017/CBO9780511808678

Oberlack, C., L. Tejada, P. Messerli, S. Rist, and M. Giger. 2016. Sustainable livelihoods in the global land rush? Archetypes of livelihood vulnerability and sustainability potentials. Global Environmental Change 41:153-171. http://dx.doi.org/10.1016/j. gloenvcha.2016.10.001

Oberlack, C., P. L. Walter, J. Schmerbeck, and B. K. Tiwari. 2015. Institutions for sustainable forest governance: robustness, equity, and cross-level interactions in Mawlyngbna, Meghalaya, India. International Journal of the Commons 9(2):670-697. http://dx.doi. org/10.18352/ijc.538

Olson, M. 1965. Logic of collective action: public goods and the theory of groups. Harvard University Press, Cambridge, Massachusetts, USA.

Ostrom, E. 1990. Governing the commons: the evolution of institutions for collective action. Cambridge University Press, 
Cambridge, UK. http://dx.doi.org/https://doi.org/10.1017/ CBO9780511807763

Ostrom, E. 1998. A behavioral approach to the rational choice theory of collective action. American Political Science Review 92 (1):1-22 http://dx.doi.org/https://doi.org/10.2307/2585925

Ostrom, E. 2005. Understanding institutional diversity. Princeton Universty Press, Princeton, New Jersey, USA.

Ostrom, E. 2007. A diagnostic approach for going beyond panaceas. Proceedings of the National Academy of Sciences of the United States of America 104(39):15181-15187. http://dx.doi. org/10.1073/pnas.0702288104

Ostrom, E. 2009. A general framework for analyzing sustainability of social-ecological systems. Science 325 (5939):419-422. http://dx.doi.org/10.1126/science.1172133

Ostrom, E., and M. Cox. 2010. Moving beyond panaceas: a multitiered diagnostic approach for social-ecological analysis. Environmental Conservation 37(4):451-463. http://dx.doi.org/10.1017/ $\underline{\mathrm{S} 0376892910000834}$

Ostrom, E., R. Gardner, and J. Walker. 1994. Rules, games, and common-pool resources. University of Michigan Press, Ann Arbor, Michigan, USA. http://dx.doi.org/10.3998/mpub.9739

Oviedo, A. F. P., and M. Bursztyn. 2016. The fortune of the commons: participatory evaluation of small-scale fisheries in the Brazilian Amazon. Environmental Management 57(5):1009-1023. http://dx.doi.org/10.1007/s00267-016-0660-Z

Partelow, S. 2015. Key steps for operationalizing social-ecological system framework research in small-scale fisheries: a heuristic conceptual approach. Marine Policy 51:507-511. http://dx.doi. org/10.1016/j.marpol.2014.09.005

Partelow, S. 2016. Coevolving Ostrom's social-ecological systems (SES) framework and sustainability science: four key co-benefits. Sustainability Science 11(3):399-410. http://dx.doi.org/10.1007/ $\underline{\mathrm{s} 11625-015-0351-3}$

Partelow, S., and C. Boda. 2015. A modified diagnostic socialecological system framework for lobster fisheries: case implementation and sustainability assessment in southern California. Ocean and Coastal Management 114:204-217. http:// dx.doi.org/10.1016/j.ocecoaman.2015.06.022

Partelow, S., M. Fujitani, V. Soundararajan, and A. Schlüter. In review. Transforming the social-ecological systems framework into a knowledge exchange and deliberation tool for comanagement. Ecology and Society

Partelow, S., M. Glaser, S. Solano, R. Barboza, and A. Schlüter. 2018a. Mangroves, fishers, and struggle for adaptive comanagement: applying the social-ecological systems framework to a marine extractive research (RESEX) in Brazil. Ecology and Society 23(3): 19. http://dx.doi.org/https://doi.org/10.5751/ ES-10269-230319

Partelow, S., P. Senff, N. Buhari, and A. Schlüter. $2018 b$. Operationalizing the social-ecological systems framework in pond aquaculture. International Journal of the Commons 12 (1):485-518. http://dx.doi.org/https://doi.org/10.18352/ijc.834
Partelow, S., and K. J. Winkler. 2016. Interlinking ecosystem services and Ostrom-s framework through orientation in sustainability research. Ecology and Society 21(3): 27. http://dx. doi.org/https://doi.org/10.5751/ES-08524-210327

Poteete, A., M. A. Janssen, and E. Ostrom. 2010. Working together: collective action, the commons and multiple methods in practice. Princeton Universty Press, Princeton, New Jersey, USA. http://dx.doi.org/10.1515/9781400835157

Pretty, J. 2003. Social capital and the collective management of resources. Science 302(5652):1912-1914. http://dx.doi.org/10.1126/ science. 1090847

Rahimi, S., S. D. Gaines, S. Gelcich, R. Deacon, and D. Ovando. 2016. Factors driving the implementation of fishery reforms. Marine Policy 71:222-228. http://dx.doi.org/10.1016/j.marpol.2016.06.005

Ratajczyk, E., U. Brady, J. A. Baggio, A. J. Barnett, N. Rollins, C. A. Rubinos, H. C. Shin, J. Y. David, R. Aggarwal, J. M. Anderies, and M. A. Janssen. 2016. Challenges and opportunities in coding the commons: problems, procedures, and potential solutions in large-n comparative case studies. International Journal of the Commons 10(2):440-466. http://dx.doi. org/10.18352/ijc.652

Raworth, K. 2012. A safe and just space for humanity: can we live within the doughnut? Oxfam discussion paper, Oxfam, London, UK.

Risvoll, C., G. E. Fedreheim, A. Sandberg, and S. BurnSilver. 2014. Does pastoralists' participation in the management of national parks in northern Norway contribute to adaptive governance? Ecology and Society 19(2): 71. http://dx.doi.org/ https://doi.org/10.5751/ES-06658-190271

Rodríguez-Robayo, K. J., and L. Merino-Perez. 2017. Contextualizing context in the analysis of payment for ecosystem services. Ecosystem Services 23:259-267. http://dx.doi.org/10.1016/ j.ecoser.2016.12.006

Rova, S., and F. Pranovi. 2017. Analysis and management of multiple ecosystem services within a social-ecological context. Ecological Indicators 72:436-443. http://dx.doi.org/10.1016/j. ecolind.2016.07.050

Schlager, E. 2004. Common-pool resource theory. Pages 145-175 in R. O'Leary, D. J. Fiorino, and R. F. Durant, editors. Environmental governance reconsidered. MIT Press, Cambridge, Massachusetts, USA.

Schlüter, A., and R. Madrigal. 2012. The SES framework in a marine setting: methodological lessons *. Rationality, Markets and Morals 3:148-167.

Schlüter, A., S. Partelow, L. E. T. Guevara, and T. Jennerjahn. 2019. Coastal commons as social-ecological systems. In $\mathrm{B}$. Hudson, J. Rosenbloom, and D. Cole, editors. Handbook of the study of the commons. Routledge, London, UK. [in press.]

Schlüter, A., S. Wise, K. Schwerdtner-Mánez, G. de Morais, and M. Glaser. 2013. Institutional change, sustainability and the sea. Sustainability 5(12):5373-5390. http://dx.doi.org/10.3390/su5125373 
Schlüter, M., J. Hinkel, P. W. G. Bots, and R. Arlinghaus. 2014. Application of the SES framework for model-based analysis of the dynamics of social-ecological systems. Ecology and Society 19(1): 36. http://dx.doi.org/10.5751/ES-05782-190136

Sharma, D., I. Holmes, G. Vergara-Asenjo, W. N. Miller, M. Cunampio, R. B. Cunampio, M. B. Cunampio, and C. Potvin. 2016. A comparison of influences on the landscape of two socialecological systems. Land Use Policy 57:499-513. http://dx.doi. org/10.1016/j.landusepol.2016.06.018

Silva, A. C. S., C. O. Galvão, and G. N. S. Silva. 2015. Droughts and governance impacts on water scarcity: an analysis in the Brazilian semi-arid. Proceedings of the International Association of Hydrological Sciences 369:129-134. http://dx.doi.org/10.5194/ piahs-369-129-2015

Stevenson, T. C., and B. N. Tissot. 2014. Current trends in the analysis of co-management arrangements in coral reef ecosystems: a social-ecological systems perspective. Current Opinion in Environmental Sustainability 7:134-139. http://dx.doi. org/10.1016/j.cosust.2014.02.002

Taggart-Hodge, T. D., and M. Schoon. 2016. The challenges and opportunities of transboundary cooperation through the lens of the east carpathians biosphere reserve. Ecology and Society 21(4): 29. http://dx.doi.org/10.5751/ES-08669-210429

Thiel, A., M. E. Adamseged, and C. Baake. 2015. Evaluating an instrument for institutional crafting: how Ostrom's socialecological systems framework is applied. Environmental Science and Policy 53:152-164. http://dx.doi.org/10.1016/j.envsci.2015.04.020

Villamayor-Tomas, S., A. Thiel, S. Villamayor-Tomas, F. D. Fleischman, I. P. Ibarra, and F. van Laerhoven. 2014. From Sandoz to Salmon: conceptualizing resource and institutional dynamics in the Rhine watershed through the SES framework. International Journal of the Commons 8(2):361-395. http://dx.doi. org/10.18352/ijc.411

Vogt, J. M., G. B. Epstein, S. K. Mincey, B. C. Fischer, and P. McCord. 2015. Putting the "E" in SES: unpacking the ecology in the Ostrom social-ecological system framework. Ecology and Society 20(1): 55. http://dx.doi.org/10.5751/ES-07239-200155

Williams, K. W., and H.-S. Tai. 2016. A multi-tier social-ecological system analysis of protected areas co-management in Belize. Sustainability 8(2): 104. http://dx.doi.org/10.3390/su8020104

Wollenberg, E., L. Merino, A. Agrawal, and E. Ostrom. 2007. Fourteen years of monitoring community-managed forests: learning from IFRI's experience. International Forestry Review 9 (2):670-684. http://dx.doi.org/10.1505/ifor.9.2.670

Yandle, T., D. S. Noonan, and B. Gazley. 2016. Philanthropic support of national parks: analysis using the social-ecological systems framework. Nonprofit and Voluntary Sector Quarterly 45 (4):134S-155S. http://dx.doi.org/10.1177/0899764016643612

Ye, Q. 2014. Building resilient power grids from integrated risk governance perspective: a lesson learned from China's 2008 icesnow storm disaster. European Physical Journal: Special Topics 223(12):2439-2449. http://dx.doi.org/https://doi.org/10.1140/epjst/ e2014-02218-7
Yin, R., T. Liu, S. Yao, and M. Zhao. 2013. Designing and implementing payments for ecosystem services programs: lessons learned from China's cropland restoration experience. Forest Policy and Economics 35:66-72. http://dx.doi.org/10.1016/j. $\underline{\text { forpol.2013.06.010 }}$ 


\begin{tabular}{|c|c|}
\hline $\begin{array}{l}\text { 2nd tier variable } \\
\text { name and code }\end{array}$ & Indicators used/ potential indicators to use/ definitions \\
\hline $\begin{array}{l}\text { Economic } \\
\text { development (S1) }\end{array}$ & $\begin{array}{l}\text { Economic growth (e.g. GDP); Standards of living; Economic health of the } \\
\text { area (e.g. number of jobs, sectors, diversification) }\end{array}$ \\
\hline $\begin{array}{l}\text { Demographic trends } \\
\text { (S2) }\end{array}$ & Population growth; Population trends, changes and/or status \\
\hline $\begin{array}{l}\text { Political stability } \\
\text { (S3) }\end{array}$ & $\begin{array}{l}\text { Regulatory framework of country or region; Regularity rules and values } \\
\text { present }\end{array}$ \\
\hline $\begin{array}{l}\text { Other governance } \\
\text { systems (S4) }\end{array}$ & $\begin{array}{l}\text { Traditional tenure/ simple operational rules; Government resource policies; } \\
\text { Top-down policies adopted by the national, regional and local governments }\end{array}$ \\
\hline Markets (S5) & $\begin{array}{l}\text { Market demand; Tour operators; Environmental awareness; Market } \\
\text { conditions; Markets for natural resources and conservation incentives; } \\
\text { Distance to external markets }(\mathrm{km})\end{array}$ \\
\hline $\begin{array}{l}\text { Media organizations } \\
\text { (S6) }\end{array}$ & Number, diversity and freedom of private and public media \\
\hline Technology (S7) & $\begin{array}{l}\text { Relevant technology present; Communication (e.g. mobile phones, } \\
\text { broadcasting, information storage) }\end{array}$ \\
\hline $\begin{array}{l}\text { Clarity of system } \\
\text { boundaries (RS1) }\end{array}$ & $\begin{array}{l}\text { Resource unit distribution; Resource unit recruitment sourcing (within/outside } \\
\text { governance system boundaries); Zoning districts/Marine Protected Areas; } \\
\text { International boundaries (e.g. EEZ, national borders); Clarity of the system's } \\
\text { geographical, social and legal boundaries; Biophysical characteristics that } \\
\text { make it feasible for actors to determine where the resource system starts or } \\
\text { ends }\end{array}$ \\
\hline $\begin{array}{l}\text { Size of resource } \\
\text { system (RS2) }\end{array}$ & $\begin{array}{l}\text { Absolute or relative descriptions of the spatial extent; Size in appropriate units } \\
\text { (e.g. square kilometers, square miles); Carrying capacity of for relevant } \\
\text { species; Size of relevant system patches of interest; Area of exclusive interest } \\
\text { or value within system; Physical proximity to markets; Area under } \\
\text { management (e.g. irrigation); Percentage of system under production; } \\
\text { Percentage area of system under different production systems }\end{array}$ \\
\hline $\begin{array}{l}\text { Human-constructed } \\
\text { facilities (RS3) }\end{array}$ & $\begin{array}{l}\text { Tourism industry infrastructure; Resource units storage facilities (e.g. tank- } \\
\text { houses, lobster cages, fish pens); Irrigation infrastructures; Access structures } \\
\text { (e.g. piers, harbors, trails, airport); Artificial habitat; Accommodation } \\
\text { facilities; Anthropogenic structures facilitating resource management (e.g. } \\
\text { fences, access ways, storage or transformation facilities); Tracking and/or data } \\
\text { infrastructure }\end{array}$ \\
\hline
\end{tabular}




\begin{tabular}{|c|c|}
\hline $\begin{array}{l}\text { Productivity of } \\
\text { system (RS4) }\end{array}$ & $\begin{array}{l}\text { Population/ stock status; Biophysical properties; Biodiversity; Species risk; } \\
\text { Biomass produced; Qualitative estimation of productivity; Number of users/ } \\
\text { visitors; Production-consumption rates per unit of time, surface, or volume }\end{array}$ \\
\hline $\begin{array}{l}\text { Equilibrium } \\
\text { properties (RS5) }\end{array}$ & $\begin{array}{l}\text { Temperature threshold of system; Seasonality; Electric energy; } \\
\text { Influences (positive and negative) on the equilibrium of the resource system } \\
\text { (interaction between species, or between biological and anthropological } \\
\text { systems); Consumption-reproduction-harvest ratio (e.g. of nutrients, species); } \\
\text { MSY; Characterization of the type of attractor of a resource system along a } \\
\text { range from one to multiple (chaotic) attractors }\end{array}$ \\
\hline $\begin{array}{l}\text { Predictability of } \\
\text { system dynamics } \\
\text { (RS6) }\end{array}$ & $\begin{array}{l}\text { Seasonality; Risk of extreme events(e.g. Flooding, earthquakes, volcano, } \\
\text { hurricane, fire); Rainfall variability; Weather variability; Upwelling and } \\
\text { current variability; Spatial and temporal variability of fish population; } \\
\text { Capacity to estimate the evolution and dynamics of the resource system and } \\
\text { the impact of interventions or external influences; Degree to which actors are } \\
\text { able to forecast or identify patterns in environmentally driven variability on } \\
\text { recruitment }\end{array}$ \\
\hline $\begin{array}{l}\text { Storage } \\
\text { characteristics (RS7) }\end{array}$ & $\begin{array}{l}\text { Elevation and/or slope of landscape; Retention of information about the } \\
\text { system dynamics; Degree to which the resource units can be held captive until } \\
\text { harvested }\end{array}$ \\
\hline Location (RS8) & $\begin{array}{l}\text { Locations between key system components; Geographic location (e.g. } \\
\text { coordinates); Distance to nearest hub airport; Spatial and temporal extent } \\
\text { where resource units are found by actors; Spatial and temporal extent where } \\
\text { system is or can be accessed by users }\end{array}$ \\
\hline $\begin{array}{l}\text { Resource unit } \\
\text { mobility (RU1) }\end{array}$ & $\begin{array}{l}\text { Degree of fluidity or fixed (e.g. tree vs water); Spatial and temporal } \\
\text { distribution of larvae; Spatial and temporal distribution of adults; } \\
\text { Extent of resource system/ infrastructure (e.g. Electricity grid); Temporal } \\
\text { patterns (e.g. nocturnal species); Migration patterns; Park boundaries; Speed } \\
\text { of mobility (e.g. tuna vs worms); Life cycle assessment }\end{array}$ \\
\hline $\begin{array}{l}\text { Growth and } \\
\text { replacement rate } \\
\text { (RU2) }\end{array}$ & $\begin{array}{l}\text { Modelled results of growth; Years to sexual maturity; Reproductive age; } \\
\text { years to legal commercial harvest size; Years of calving/ rearing; Life cycle } \\
\text { assessment; Absolute or relative descriptions of changes in quantities (x) of } \\
\text { resource units over time (t) }\end{array}$ \\
\hline $\begin{array}{l}\text { Interaction among } \\
\text { resource units (RU3) }\end{array}$ & $\begin{array}{l}\text { Reproduction patterns/ needs; Symbiotic relationships; Patterns/ relations } \\
\text { between resources in similar time and space (e.g. competition, collaboration); } \\
\text { Interactions among resource units during different life stages affecting the } \\
\text { future structure of the population; Ecosystem structure/ trophic interactions } \\
\text { (e.g. keystone species, Dependencies between species) }\end{array}$ \\
\hline $\begin{array}{l}\text { Economic value } \\
\text { (RU4) }\end{array}$ & $\begin{array}{l}\text { Price per kilo; Cultural value of individual resource units; Value of total } \\
\text { annual landings/ harvest; Quality of resource; Value of units per unit area; } \\
\text { Nutritional value (Calorific value/ha, Calories produced/ha, Protein }\end{array}$ \\
\hline
\end{tabular}




\begin{tabular}{|c|c|}
\hline & $\begin{array}{l}\text { produced/ha, Fodder quality-nutritional content of fodder); Differences } \\
\text { between live and dead/ frozen value; Market predictability; Market diversity; } \\
\text { Recreational value; Opportunity Costs; Non-market values; Value ration in } \\
\text { relation to the portfolio of resources available to actors }\end{array}$ \\
\hline $\begin{array}{l}\text { Number of units } \\
\text { (RU5) }\end{array}$ & $\begin{array}{l}\text { Total catch per year (tons); catch per individual gear type; Catch per unit } \\
\text { effort; Differentiation between unit types (e.g. Domesticated vs wild units); } \\
\text { Percent land cover (e.g. forest cover or density); Legal harvest rate vs Illegal, } \\
\text { Unreported, Unregulated (IUU) rate; Total volume or amount of resource (e.g. } \\
\text { wood volume, agriculture production volume), Number of activities for users } \\
\text { (e.g. in a park, ocean); Number that could be potentially harvested }\end{array}$ \\
\hline $\begin{array}{l}\text { Distinctive } \\
\text { characteristics (RU6) }\end{array}$ & $\begin{array}{l}\text { Male/ female differences; Age differences; Reproductive indicators (e.g. } \\
\text { carrying eggs, molting, behavioral signs); Artificial markings (e.g. branding, } \\
\text { tagging, v-notch for lobsters); Landscape features; } \\
\text { Markings and/or behavioral patterns that can be identified in resource units } \\
\text { and affect actors' behavior toward them }\end{array}$ \\
\hline $\begin{array}{l}\text { Spatial and temporal } \\
\text { distribution (RU7) }\end{array}$ & $\begin{array}{l}\text { Elevation or depth distributions per unit time; Coverage or density across area } \\
\text { per unit time; Migration patterns; Seasonality; Larval distribution range; } \\
\text { Geographic limitations; Species range; Range/ distribution of viable habitat or } \\
\text { food sources }\end{array}$ \\
\hline $\begin{array}{l}\text { Government } \\
\text { organizations (GS1) }\end{array}$ & $\begin{array}{l}\text { Government regulators; Public-private initiatives; Administrative } \\
\text { Levels present(e.g National, Regional, Local); Support Enforcement; Support } \\
\text { Funding available; Number Government departments; Quasi-government } \\
\text { organisations (e.g. Combined state and civil society managed agencies); } \\
\text { Presence or absence of different organizations at local level; Institutions } \\
\text { present with governmental authority }\end{array}$ \\
\hline NGOs (GS2) & $\begin{array}{l}\text { Presence of organizations or active initiatives; Conservation/ environmental } \\
\text { organizations; Universities/ research organizations; Private sector institutions; } \\
\text { Voluntary initiatives;; Social/Welfare Organizations; Restoration orgs; NGOs } \\
\text { at different levels (e.g. International, National, Local, Community-based } \\
\text { organizations); Other } \\
\text { institutions without governmental authority mandated }\end{array}$ \\
\hline $\begin{array}{l}\text { Network structure } \\
\text { (GS3) }\end{array}$ & $\begin{array}{l}\text { Funding providers; Multilevel governance structure; Vertical structure; } \\
\text { Horizontal structure; Transparency; Vertical and horizontal partners in co- } \\
\text { management; Representation of actors; Stakeholder participation options; } \\
\text { Information flows; Network configuration at local level and their interactions; } \\
\text { Administrative structure of organization; Social or political connections } \\
\text { among the rule-making organizations and the population subject to these rules }\end{array}$ \\
\hline $\begin{array}{l}\text { Property rights } \\
\text { systems (GS4) }\end{array}$ & $\begin{array}{l}\text { Presence of property rights systems (e.g. Open access, private property, } \\
\text { common property and no access); Informal or traditional tenure systems; } \\
\text { Quotas; Lease agreements; Security and/or strength of tenure; Percentage of } \\
\text { system with property rights; Local property-rights systems and their relation }\end{array}$ \\
\hline
\end{tabular}




\begin{tabular}{|c|c|}
\hline & $\begin{array}{l}\text { to resource management; Conflict between multiple property rights systems; } \\
\text { Particular types of rules determining which actors have been authorized to } \\
\text { carry out which actions with respect to a specified good or service; Patents/ } \\
\text { licensing agreements; Different forms of privatization; Strength of land rights }\end{array}$ \\
\hline $\begin{array}{l}\text { Operational choice } \\
\text { rules (GS5) }\end{array}$ & $\begin{array}{l}\text { Presence of formal written rules (e.g. legislation, legal documents, community } \\
\text { documents); Rules for resource harvesting and distribution (e.g. size limits, } \\
\text { seasonal closures, species distinctions, quotas, harvesting limits, caps on } \\
\text { pollution, etc) } \\
\text { Presence of informal rules (e.g. non-written agreements, norms, etc.) }\end{array}$ \\
\hline $\begin{array}{l}\text { Collective choice } \\
\text { rules (GS6) }\end{array}$ & $\begin{array}{l}\text { Presence of formal and/or informal rules related to actor participation, } \\
\text { collective action procedures and/or decision making processes to modify } \\
\text { operational rules; Structure of management; User group distinctions; Level of } \\
\text { stakeholder involvement; The processes through which institutions are } \\
\text { constructed and policy decisions made by actors authorized (or allowed) to do } \\
\text { so; Rules set defined by involved actors according to local environment and } \\
\text { political and economic conditions }\end{array}$ \\
\hline $\begin{array}{l}\text { Constitutional } \\
\text { choice rules (GS7) }\end{array}$ & $\begin{array}{l}\text { Presence of regulatory framework under which collective choice and } \\
\text { operational rules are situated within; National law; Legal mandates; } \\
\text { International law; Taxation; Subsidies; Conservation regulations; Legal } \\
\text { framework defined by regional and national governments; The process } \\
\text { through which collective-choice procedures are defined and legitimized. }\end{array}$ \\
\hline $\begin{array}{l}\text { Monitoring and } \\
\text { sanctioning (GS8) }\end{array}$ & $\begin{array}{l}\text { Presence of enforcement authority; Locally adapted processes to monitor and } \\
\text { sanction natural resource use and management strategies; Local actors or } \\
\text { those legitimized by them are responsible to observe and report changes in the } \\
\text { SES; Monitoring social or biophysical changes; Data collection activities; } \\
\text { Graduated sanctions(Whether sanctions increase with numerous offenses) }\end{array}$ \\
\hline $\begin{array}{l}\text { Number of actors } \\
\text { (A1) }\end{array}$ & $\begin{array}{l}\text { Number of resource harvesters/ users; Number of boats/gear to access system; } \\
\text { Number of different actor groups; Population growth per unit time; } \\
\text { Availability of labour; Labour reduction( time taken to perform task); Number } \\
\text { of IUU actors; Size of community; Number of representatives on management } \\
\text { committee; Population in surrounding areas }\end{array}$ \\
\hline $\begin{array}{l}\text { Socioeconomic } \\
\text { attributes (A2) }\end{array}$ & $\begin{array}{l}\text { Income; Age; Gender; Affluence; Tourism firms; Economic characteristics of } \\
\text { the users; Proxies of user wealth; User welfare; Labor availability;; Year of } \\
\text { household establishment; Number of people at home; Number of children at } \\
\text { home; Number of elders at home; Age of eldest; Assets owned (Y or N); } \\
\text { Education level of household head; Place of origin of household head; } \\
\text { Immigration status; Socioeconomic resilience (e.g. Insurance availability); } \\
\text { Operating costs (Replacement/renewal rates); Number of livelihoods; } \\
\text { Population share below age 18; Unemployment status; Median income; Share } \\
\text { in top quartile of country income; Ethnicity; Age of surrounding buildings; } \\
\text { Material style of life; Education and knowledge }\end{array}$ \\
\hline History or past & Historical resource use; Experienced/ exposure crisis or extreme events; \\
\hline
\end{tabular}




\begin{tabular}{|c|c|}
\hline experiences (A3) & $\begin{array}{l}\text { Duration living in area or using resources; Chronological description of the } \\
\text { main events related to the resources and its management; Year founded (e.g. } \\
\text { village, city, park); Process of management over time; Age of users/ group/ } \\
\text { community; Past interactions that affect current actor's behavior and fisheries } \\
\text { dynamics }\end{array}$ \\
\hline Location (A4) & $\begin{array}{l}\text { Is system remote and isolated; Clarity of boundaries; Exclusion problems; } \\
\text { Geographic proximity to resource/ system; Distance to resources; } \\
\text { Port/Harbors/Built Infrastructures (Man-made); Beaches/ Non-built/ natural } \\
\text { access (Natural); Geographical location of resource system's users (e.g. } \\
\text { settlements, villages, dispersed); Physical place where the actors are in } \\
\text { relation to the resource itself and the market }\end{array}$ \\
\hline $\begin{array}{l}\text { Leadership/ } \\
\text { entrepreneurship } \\
\text { (A5) }\end{array}$ & $\begin{array}{l}\text { Presence of formal leaders; Educated and well-connected leaders are present; } \\
\text { Active individual(s) to lead collective action; Existence of, and attitude } \\
\text { towards leadership and entrepreneurship among users; Local individuals who } \\
\text { are capable of leading resource management and are respected by their peers; } \\
\text { Actors who have skills useful to organize collective action and are followed } \\
\text { by their peers; Trust in community }\end{array}$ \\
\hline $\begin{array}{l}\text { Norms, trust, social } \\
\text { capital (A6) }\end{array}$ & $\begin{array}{l}\text { Closeness of community; Degree of shared norms; Substantial social capital; } \\
\text { "Sticking together"; Spatially significant organization of actors } \\
\text { (Clubs/Organizations/Chapters); Non-spatially significant organization of } \\
\text { actors ( Online format, publications); Social capital( Degree to which each } \\
\text { actor can depend on the other; actors share the same code of ethics and } \\
\text { develop levels of trust; Motivations and attitudes of actors; Confidence and } \\
\text { cooperation among actors; Levels of social and institutional interactions } \\
\text { among users, including aspects like reciprocity and trust; Years of educational } \\
\text { attainment; Voter turnout rates; Trust in community ;Migration status; } \\
\text { Attendance at community events; Social network strength }\end{array}$ \\
\hline $\begin{array}{l}\text { Knowledge of SES/ } \\
\text { mental models (A7) }\end{array}$ & $\begin{array}{l}\text { Education rates; Degree of knowledge about system; Educational level of the } \\
\text { user; Number of trainings received/a certain period of time; Presence/ degree } \\
\text { of Traditional ecological knowledge (TEK); Presence/ degree of Western } \\
\text { science and management knowledge (SMK); Presence/ degree of Local } \\
\text { ecological knowledge (LEK); Degree of knowledge sharing/social } \\
\text { learning;Which perceptions exist and how are they formed by SES conditions } \\
\text { Management practices; Level of knowledge among the users of the SES } \\
\text { conditions, the potential and real disturbance patterns and its possible effects; } \\
\text { Degree to which stakeholders understand and make sense of the } \\
\text { characteristics and/or dynamics of the SES; Human agency (Perceptions abou } \\
\text { whether human activities can increase the number of fish in the sea) }\end{array}$ \\
\hline $\begin{array}{l}\text { Importance of } \\
\text { resource } \\
\text { (dependence) (A8) }\end{array}$ & $\begin{array}{l}\text { Number of alternative livelihood opportunities; Degree of economic } \\
\text { dependence; Degree of social/ cultural dependence; Occupational diversity; } \\
\text { Dependence on natural system to sustain livelihood; Dependence on } \\
\text { subsidies; Land ownership }\end{array}$ \\
\hline $\begin{array}{l}\text { Technologies } \\
\text { available (A9) }\end{array}$ & $\begin{array}{l}\text { Degree of access to appropriate technologies; Number of technologies } \\
\text { adopted over time; Percent of land on which a technology has been adopted; }\end{array}$ \\
\hline
\end{tabular}




\begin{tabular}{|c|c|}
\hline & $\begin{array}{l}\text { Percentage of users adopting a technology; } \\
\text { What technology is used for harvesting, repairing, access, communication, } \\
\text { decision making, management }\end{array}$ \\
\hline $\begin{array}{l}\text { Climate patterns } \\
(\text { ECO1) }\end{array}$ & $\begin{array}{l}\text { Sea level rise; Climate change; Coral bleaching; Ocean acidification; } \\
\text { Bioühyiscal changes in system }\end{array}$ \\
\hline $\begin{array}{l}\text { Pollution patterns } \\
(\text { ECO2) }\end{array}$ & $\begin{array}{l}\text { Levels of toxic chemicals or materials; Presence of point sources (e.g. runoff } \\
\text { pipes, rivers); Regional pollution pattern trends }\end{array}$ \\
\hline $\begin{array}{l}\text { Flows in/out of SES } \\
\text { (ECO3) }\end{array}$ & -- \\
\hline Harvesting (I1) & Quantity of resources harvested by different users \\
\hline $\begin{array}{l}\text { Information sharing } \\
\text { (I2) }\end{array}$ & $\begin{array}{l}\text { Forums and media to keep actors abreast of developments; Methods for } \\
\text { information sharing among users; Exchange of information regarding } \\
\text { management process through written or spoken means }\end{array}$ \\
\hline $\begin{array}{l}\text { Deliberation } \\
\text { processes (I3) }\end{array}$ & $\begin{array}{l}\text { Presence of organizational/ decision making processes among users; } \\
\text { participation of users }\end{array}$ \\
\hline Conflicts (I4) & $\begin{array}{l}\text { Presence of forums to address conflicts and reach amenable conclusions); } \\
\text { Existence of new types of actors (foreign tourists, kiters); Presence of existing } \\
\text { conflicts among users }\end{array}$ \\
\hline $\begin{array}{l}\text { Investment activities } \\
\text { (I5) }\end{array}$ & $\begin{array}{l}\text { Presence of subsidies; Private investment or development; Building of human } \\
\text { and resource capacity in SES; Investments for improving and managing the } \\
\text { resources (e.g. time, money); Budgets (in dollars per visitor) }\end{array}$ \\
\hline $\begin{array}{l}\text { Lobbying activities } \\
\text { (I6) }\end{array}$ & Internal and external influential capacity of the users \\
\hline $\begin{array}{l}\text { Self-organizing } \\
\text { activities (I7) }\end{array}$ & $\begin{array}{l}\text { Collective action activities to govern SES; Internal rules for the extraction and } \\
\text { management of resources among users }\end{array}$ \\
\hline $\begin{array}{l}\text { Networking } \\
\text { activities (I8) }\end{array}$ & $\begin{array}{l}\text { Interactions within the social sub-system (e.g Informal networks; Formal } \\
\text { networks); Liaise with horizontal and vertical partners to foster collective } \\
\text { action; Networking and partnership activities of the users within and outside } \\
\text { the community; market access }\end{array}$ \\
\hline $\begin{array}{l}\text { Monitoring activities } \\
\text { (I9) }\end{array}$ & $\begin{array}{l}\text { Monitoring activities on the use and management of resources (e.g. locally- } \\
\text { defined by users, controlled by the government) and their performance; }\end{array}$ \\
\hline
\end{tabular}




\begin{tabular}{|c|c|}
\hline & Community-based monitoring of social and/or ecological outcomes \\
\hline $\begin{array}{l}\text { Evaluative activities } \\
\text { (I10) }\end{array}$ & $\begin{array}{l}\text { Processes of evaluation of the resource situation and of the effects of } \\
\text { management initiatives }\end{array}$ \\
\hline $\begin{array}{l}\text { Social performance } \\
\text { measures }(\mathrm{O} 1)\end{array}$ & $\begin{array}{l}\text { Co-management outcomes; Coproduction of knowledge; efficiency; learning; } \\
\text { Evolution and impacts of the socio-economic characteristics; } \\
\text { Measure of social outcomes resulting from interactions; Perceived impacts on } \\
\text { livelihoods; gender equity; resource use efficiency }\end{array}$ \\
\hline $\begin{array}{l}\text { Ecological } \\
\text { performance } \\
\text { measures (O2) }\end{array}$ & $\begin{array}{l}\text { Ecosystem services; Wildlife conservation; Evolution and impacts of the } \\
\text { ecological conditions; Measure of ecological outcomes resulting from } \\
\text { interactions; GHG emissions; soil erosion; agricultural yield; water footprint; } \\
\text { livestock welfare; yield gap; yield variability; CO2 emissions; salinization; } \\
\text { carbon sequestration }\end{array}$ \\
\hline $\begin{array}{l}\text { Externalities to other } \\
\text { SES (O3) }\end{array}$ & Non desired effects (positive and negative) that occur as results of processes \\
\hline
\end{tabular}

